\title{
Coalbed Methane As A New Source of Energy In Indonesia And Some Developed Countries; A Review
}

\author{
Hamdani Wahab ${ }^{\mathrm{a}}$, Mohammad Barbarosa ${ }^{\mathrm{a}}$, Awaludin Martin ${ }^{\mathrm{a},{ }^{*}}$ \\ a) Mechanical Engineering Department, Universitas Riau, Indonesia \\ *Corresponding author: awaludinmartin01@gmail.com
}

\author{
Article History \\ Received: 01-June-2021 \\ Received in revised form: 01-July-2021 \\ Accepted: 30-July-2021
}

\begin{abstract}
The decrease in conventional energy sources followed by the world's energy demand as well as mounting concern about climate change, the countries are competing to get new sources of environmentally friendly energy with large reserves. The utilization of CBM as a new energy is an option because of its huge reserves, more environmentally friendly than traditional fossil energy (CBM emissions are 0.39 tones/MWh) and energy efficiency equivalent to natural gas. Indonesia has huge CBM reserves (400 TCF) but has not been utilize optimally due to technological problems, government regulations, large investments and others. This issues plus geographical constraints also occurs in countries with huge CBMs resource such as Russia (450 TCF) and China (700 TCF). Meanwhile, USA (500 TCF) and Australia (500 TCF) already have more established rules and technology. It is necessary to conduct a comparative study from each country according to the applicable regulations to accelerate the utilization of CBM.
\end{abstract}

KEYWORDS: Coalbed Methane, World's energy Demand, Enviromental Issues, Accelerate CBM Utilization.

$\begin{array}{ll}C B M & \text { Coalbed Methane } \\ C S G & \text { Coal Seam Gas } \\ C S M & \text { Coal Seam Methane } \\ C D I A C & \text { Carbon Dioxide Information Analysis Center } \\ C T G & \text { Coal To Gas } \\ S N G & \text { Synthetic Natural Gas } \\ B T U & \text { British Thermal Unit }\end{array}$

$\begin{array}{ll}M C F & \text { Million Cubic Feet } \\ B C F & \text { Billion Cubic Feet } \\ M W h & \text { Mega-Watt Hours } \\ T C F & \text { Trilion Cubic Feet } \\ T C M & \text { Trilion Cubic Meter } \\ K W H & \text { Kilo-Watt Hours } \\ M m s c f d & \text { Million Standard Cubic Feet per Day } \\ M W & \text { Mega-Watt } \\ G W & \text { Giga-Watt } \\ S C F / t o n & \text { Standard Cubic Foot Per Ton } \\ M C M / Y e a r & \text { Million Cubic Meters (MCM)/Year } \\ B C M & \text { Bank Cubic Meter } \\ P J & \text { Penta-Joule } \\ M T O E & \text { Million or Mega Tonnes of Oil Equivalent } \\ R E & \text { Renewable Energy } \\ V R E & \text { Variable Renewable Energy } \\ H S D & \text { High Speed Diesel } \\ K E N & \text { Kebijakan Energi Nasional } \\ U S G S & \text { United States Geological Survey } \\ A R I & \text { Advanced Resouces International } \\ I R E N A & \text { International Renewable Energy Agency } \\ E S D M & \text { Energi Sumber Daya Mineral } \\ I R R & \text { Internal Rate of Return } \\ P O D & \text { Plan Of Development }\end{array}$

\subsection{INTRODUCTION}

In recent years, the exhaustion of fossil fuels, such as coal, natural gas , and oil, has become a global concern [1]. As shown in table 1, the fossil fuel reserves such as natural gas, coal and oil in several countries in the world are decreasing. Thus, replace fossil fuels with new and renewable energy is very important.

A non-conventional energy such as a new and renewable energy will be attractive and economical if it can meet 3 current energy crises namely affordability of energy sources (affordability), security of energy use (energy security) and sustainability and environmental friendliness (Environmental sustainability) [2]. 
(C) 2012 ISOMAse, All rights reserved

Table 1: Fossil energy reserves in the world and the remaining extraction life [3]

\begin{tabular}{lrcc}
\hline & \multicolumn{2}{c}{ Coal } & \\
\hline & $\begin{array}{c}\text { Proved } \\
\text { Reserve, mlm } \\
\text { tonnes }\end{array}$ & $\begin{array}{c}\text { \% of } \\
\text { world } \\
\text { reserves }\end{array}$ & $\begin{array}{c}\text { Year of } \\
\text { Extraction } \\
\text { Remaining }\end{array}$ \\
\hline World & 1.035 .012 & 100 & 134 \\
Australia & 144.818 & 14 & 297 \\
China & 138.819 & 13 & 39 \\
India & 97.728 & 9 & 137 \\
Indonesia & 22.598 & 2 & 49 \\
Mongolia & 2.520 & 0 & 51 \\
Thailand & 1.063 & 0 & 65 \\
Vietnam & 3.360 & 0 & 87 \\
Japan & 350 & 1 & 252 \\
New Zealand & 7.575 & 0 & 2595 \\
Pakistan & 3.063 & 0 & 735 \\
\hline
\end{tabular}

\begin{tabular}{|c|c|c|c|}
\hline \multicolumn{4}{|c|}{ Natural Gas } \\
\hline & $\begin{array}{c}\text { Proved } \\
\text { Reserve, } \mathrm{Tcm}\end{array}$ & $\begin{array}{c}\% \text { of world } \\
\text { reserves }\end{array}$ & $\begin{array}{c}\text { Year of } \\
\text { Extraction } \\
\text { Remaining }\end{array}$ \\
\hline World & 1.035 .012 & 100 & 134 \\
\hline Australia & 144.818 & 14 & 297 \\
\hline Brunei & 138.819 & 13 & 39 \\
\hline Bangladesh & 97.728 & 9 & 137 \\
\hline China & 22.598 & 2 & 49 \\
\hline India & 2.520 & 0 & 51 \\
\hline Indonesia & 1.063 & 0 & 65 \\
\hline Malaysia & 3.360 & 0 & 87 \\
\hline Myanmar & 350 & 1 & 252 \\
\hline Papua New Guinea & 7.575 & 0 & 2595 \\
\hline
\end{tabular}

\begin{tabular}{lrcc}
\hline \multicolumn{4}{c}{ Crude Oil } \\
\hline & $\begin{array}{c}\text { Proved Reserve, } \\
\text { Thousand Mln } \\
\text { Barrels }\end{array}$ & $\begin{array}{c}\text { \% of world } \\
\text { reserves }\end{array}$ & $\begin{array}{c}\text { Year of } \\
\text { Extraction } \\
\text { Remaining }\end{array}$ \\
\hline World & 1.728 & 100 & 51 \\
Australia & 2 & 0 & 19 \\
Brunei & 1 & 0 & 27 \\
China & 26 & 2 & 18 \\
India & 5 & 0 & 14 \\
Indonesia & 3 & 0 & 10 \\
Malaysia & 3 & 0 & 11 \\
Thailand & - & 0 & 2 \\
Vietnam & 4 & 0 & 42 \\
Other Asia Pacific & 1 & 0 & 12 \\
\hline
\end{tabular}

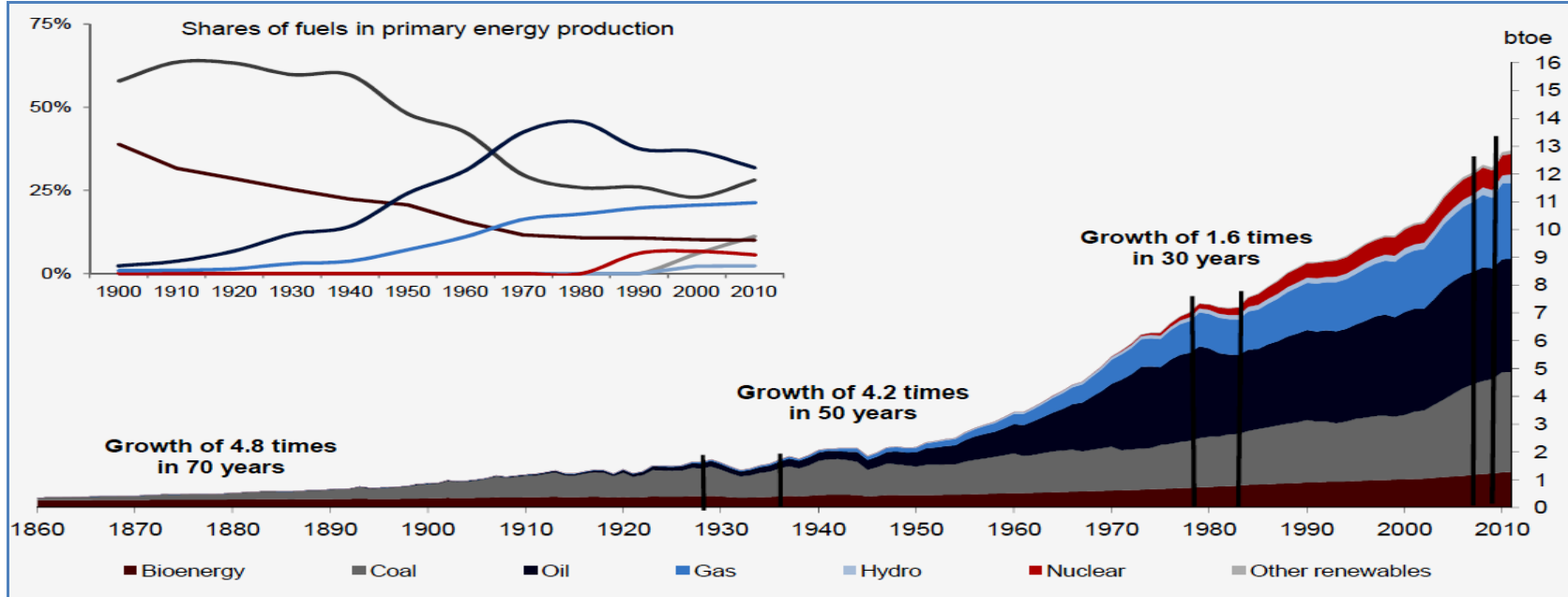

Figure 1: Energy development in the world [4]

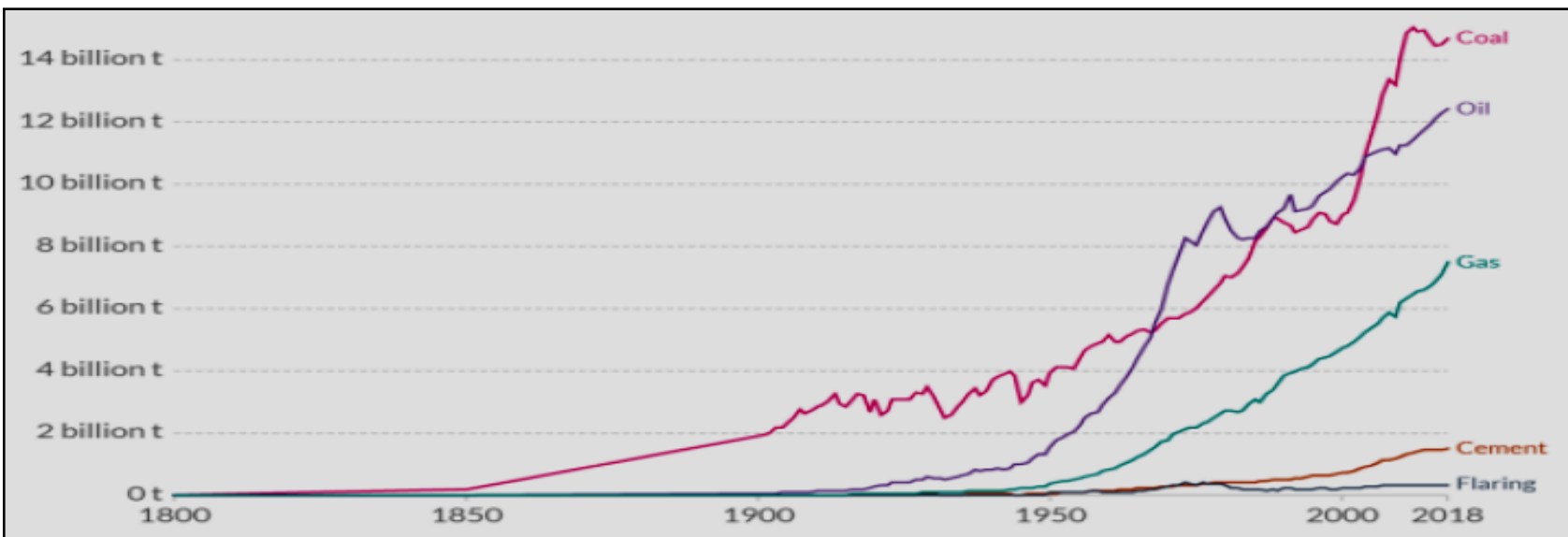

Figure 2: Comparison of $\mathrm{CO}_{2}$ emissions by fossil fuels in the world [5]

Coal and oil as energy sources that have been use in the 1880-1900 periods as shown in Figure 1 and 2 are energy with a very significant level of development and the largest emitter in the world today. Therefore, several efforts have been made to divert the use of fossil energy, especially in oil and coal, which are continuously carried out.

Coal bed methane (CBM) is one of the new and renewable energies that can meet the criteria for new and renewable energy issues such as large reserves, meeting economic factors regarding exploration and production [3]. 
Methane is the simplest gaseous hydrocarbon with the chemical formula $\mathrm{CH}_{4}$. As the main component of natural gas, methane is the primary energy source. The combustion of one molecule of methane with oxygen will release one molecule of $\mathrm{CO}_{2}$ (carbon dioxide) and two molecules of $\mathrm{H}_{2} \mathrm{O}$ (water) $\left(\mathrm{CH}_{4}+2 \mathrm{O}_{2} \rightarrow \mathrm{CO}_{2}+{ }_{2} \mathrm{H}_{2} \mathrm{O}\right)[6]$.

The concentration of methane in the atmosphere in 1998, expressed as a mole fraction, was $1,745 \mathrm{nmol} / \mathrm{mol}$ (parts per billion), up from $700 \mathrm{nmol} / \mathrm{mol}$ in 1750 . By 2008 , the content of methane gas in the atmosphere had increased again to $1,800 \mathrm{nmol} / \mathrm{mole}[7,8]$.

Methane in the earth's atmosphere is one of the main greenhouse gases (affecting the ozone layer depletion), with a global warming potential 25 times greater than $\mathrm{CO}_{2}$. This means that the impact of methane emissions is 25 times greater than carbon dioxide emissions of the same amount over a 100-year period. Methane has a large effect in the short-term period ("life" time 8.4 years in the atmosphere), while carbon dioxide has a small effect in the long-term period (more than 100 years) $[9,10]$. The concentration of methane in the atmosphere has increased $150 \%$ from 1750 and accounts for $20 \%$ of the radiation effect produced by greenhouse gases globally [9]. Methane produced from landfills will be burned to produce $\mathrm{CO} 2$ instead of methane, because this gas is more dangerous for ozone. Recently, methane that has been released into the environment on a large scale comes from the process of coal mining activities in which methane from coal deposits is released into the air during the coal mining activities [11].

Methane is one of the important fuels in generating electricity, by burning it in gas turbines or steam generators. When compared to other conventional fossil fuels, burning methane produces less carbon dioxide for each unit of heat produced. The heat of combustion produced by methane is $891 \mathrm{~kJ} / \mathrm{mol}$ [12]. This amount of heat is less than that of other hydrocarbon fuels, but if you look at the ratio between the heat produced and the molecular mass of methane $(16 \mathrm{~g} / \mathrm{mol})$, then methane will produce more heat per unit mass (55.7 $\mathrm{kJ} / \mathrm{mol})[13,14]$ than other hydrocarbons. Methane that pipes into people's homes is known as natural gas which is used for cooking and heating. Methane has an energy content of 39 mega joules per cubic meter, or 1,000 BTU per standard cubic foot [13].

Coal bed methane (CBM) is a form of natural gas methane found in coal deposits. In a geographical location containing coal accumulation, there is a coal deposit (porosity) or coal seam where gas is formed during the natural conversion of plant into coal or known as coalification [15]. In this process, coal becomes saturated with water and methane gas is trapped within it. This methane gas is adsorbed in the coal and with a decrease in pressure (reaching saturation pressure) the gas will come out through the pore spaces of the rock. CBM as non-conventional natural gas has reservoir characteristics that are different from conventional natural gas so that the concept of natural gas production cannot be applied directly [16]. This difference in characteristics has caused CBM to not be in demand in recent years because it is considered a dangerous gas and unsafe for mining. At present, according to the demands of a sustainable environment and large reserves, the negative paradigm of CBM has changed because it is clean energy according to the concept of green-house gas and resource reserves that are very economical to exploit [13].

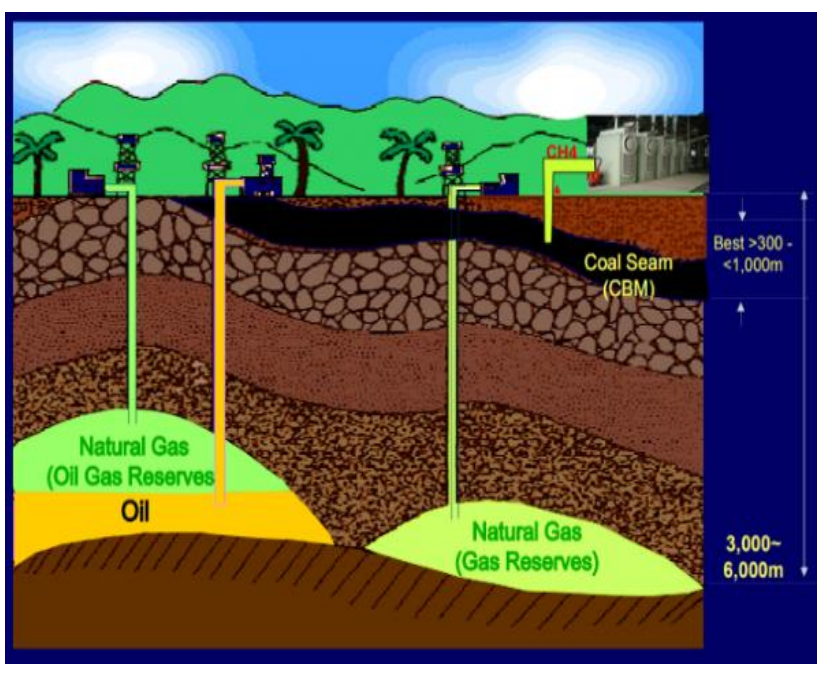

Figure 3: CBM Depth versus Gas- Conventional [20]

The composition of CBM in coal varies widely in different locations, but generally consists of methane gas $(\mathrm{CH} 4)$ and small amounts of ethane $\left(\mathrm{C}_{2} \mathrm{H}_{6}\right)$, carbon dioxide $\left(\mathrm{CO}_{2}\right)$ and water $\left(\mathrm{H}_{2} \mathrm{O}\right)$ [16]. $\mathrm{CBM}$ is a sweet gas that does not contain hydrogen sulfide $\left(\mathrm{H}_{2} \mathrm{~S}\right)$ so it is more environmentally friendly than other conventional energies [18].

The position of the CBM layer which is relatively shallower than other conventional gases also provides convenience in the exploitation process but it is considered to have an impact on climate change since in the exploration process large quantities of water are pumped from the coal seam to reduce hydrostatic pressure and reach saturation pressure [19].

The development of CBM extraction technology was first carried out in Alamabama and Southern Colorado in the late 1980s. The production stages are simple (Figure 2. CBM production process) as follows [21]:

1. Dewatering Stage: CBM is produced in smaller quantities than the co-produced water in order to obtain mechanical equilibrium and reduce pressure [13].

2. Stabil Stage: At this stage, the pressure in the reservoir will decrease so that the gas produced will increase and the amount of water produced will decrease.

3. Decline Stage: The stage of decreasing gas production with the amount of water produced is also low.

From the three stages of CBM production above, the initial capital costs for CBM production are greater than the operational costs of natural gas production, because the CBM dewatering process takes longer than the natural gas dewatering process. This causes in a period of 5-7 years, CBM operations will require large costs compared to conventional gas which only takes 1 year. Where peak production will occur in a period of 2 to 7 years and the length of the production period in the range of 10 to 20 years is shorter than natural gas which can reach 30 to 40 years [22]. After passing the dewatering stage, CBM production operating costs will be $0.03 \mathrm{US} \$ / \mathrm{MCF}$ cheaper compared to natural gas production costs [23]. This is a challenge in itself to find a new method so that the dewatering step can be more cost-effective. 


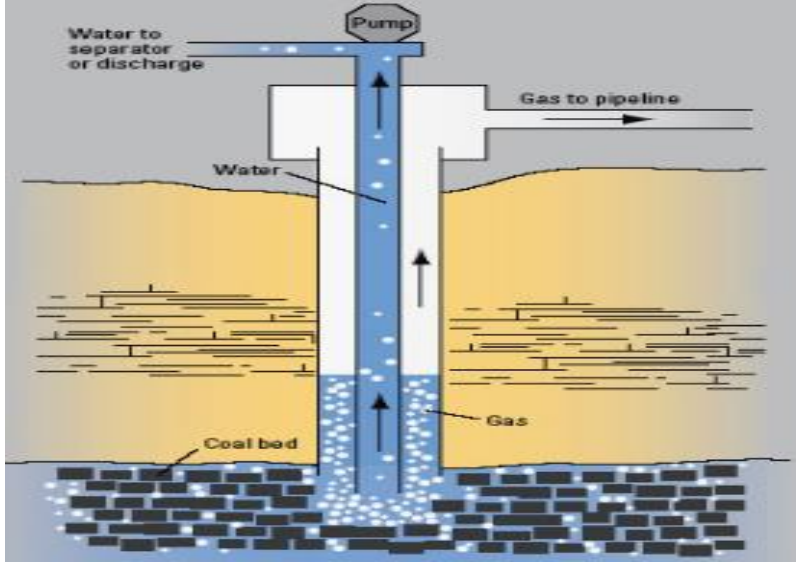

Figure 4: CBM Production Facility and dewatering process [24]

In Figure 2 of the CBM production facility above, the flow pipe from the production well carries water to the storage tank and gas with a compressor to the gas processing unit.

The water that is also produced is managed in accordance with environmental regulations and water resources and can then be used in coal preparation plants to separate the prytic sulfur content so that coal with high sulfur levels can meet the quality used in modern power plants, savings on generating facilities that must have exhaust gas desulfurization units (srubbers) whose function is to scrub sulfur out of the smoke from coal-burning boilers.

These coal mines are usually located very close to the CBM well area so that the production process and conversion of coal into electricity will be more cost-effective as well as overcome problems in the CBM dewatering process which is expensive and has the potential to damage the environment if not treated properly $[25,26]$.

From Table 1 comparison of thermal efficiency and $\mathrm{CO} 2$ emissions, conventional natural gas has the same utilization characteristics as CBM, so it can be concluded that CBM can be used to replace conventional natural gas consumption as fuel for power plants.

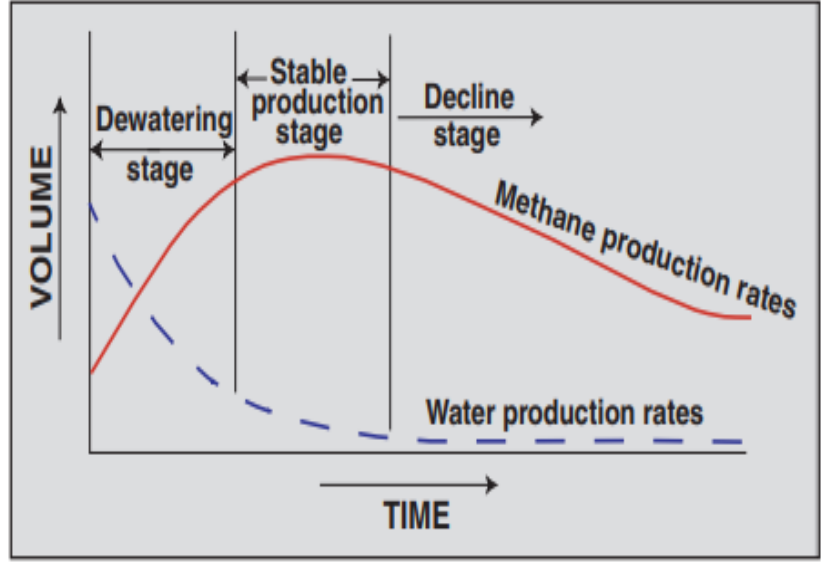

Figure 5: CBM production curve and Dewaterization [24]

Table 2: Thermal Efficiency and $\mathrm{CO}_{2}$ Emissions at generators with different fuels [27]

\begin{tabular}{lcc}
\hline $\begin{array}{c}\text { Power Generation - Fuel } \\
\text { Type }\end{array}$ & $\begin{array}{c}\text { Thermal } \\
\text { Efficiency (\%) }\end{array}$ & $\begin{array}{c}\mathrm{CO}_{2} \text { Emissions } \\
\text { (tonnes/MWh) }\end{array}$ \\
\hline $\begin{array}{l}\text { Combined Cycle } \\
\text { Natural Gas or CBM }\end{array}$ & $48-55$ & 0,39 \\
$\begin{array}{l}\text { Thermal - Natural Gas } \\
\text { or CBM }\end{array}$ & 38 & 0,49 \\
$\begin{array}{l}\text { Thermal - Black Coal } \\
\text { Thermal - Brown Coal }\end{array}$ & 35 & 0,93 \\
\end{tabular}

CBM from the coal reservoir will be pumped using an artificial lift where the water produced will be cleaned at the water treatment plant while methane gas will be collected at the Gas Collection Point (GCP) for further processing through the gas separator unit and compressed in the gas compression unit, clean methane gas and compressed will be sent to the power plant to fuel the gas generator [28, 29].

The depth of CBM contained by coal seams is different in each region, thus affecting the extraction process and CBM production as shown in Figure 6.

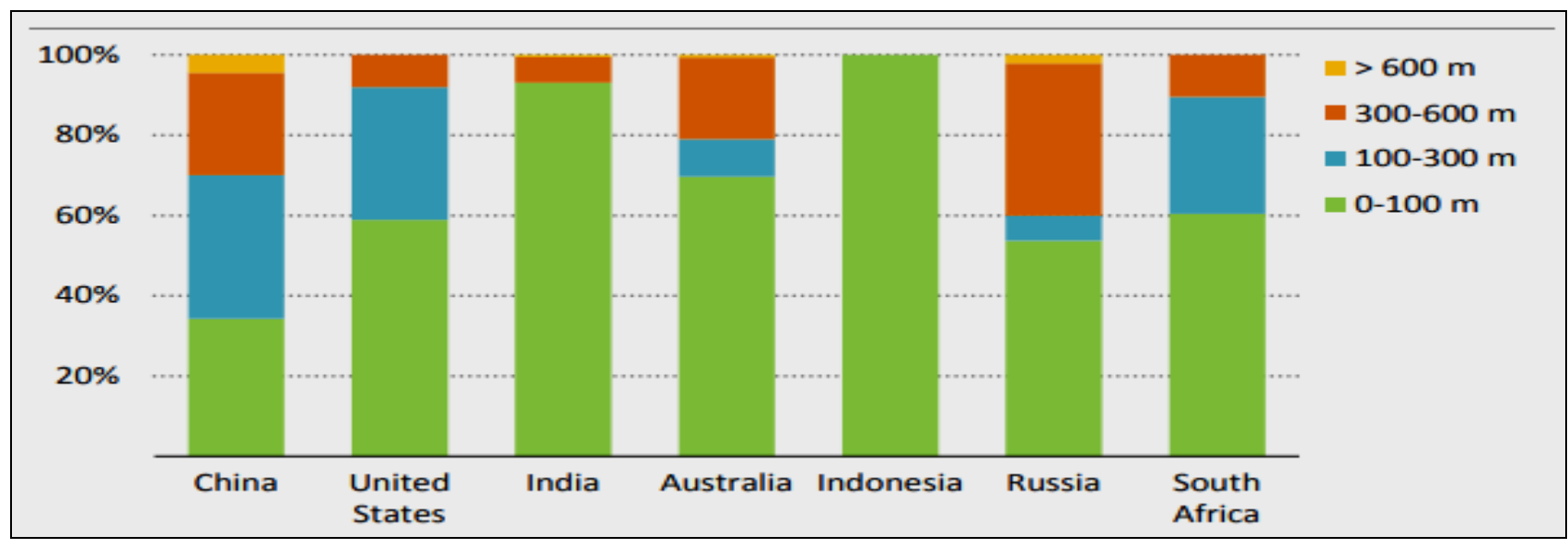

Figure 6: Depth of CBM in some countries [4] 


\subsection{METHODOLOGY}

This paper is a review of the utilization of CBM in Indonesia, Russia, the United States, Australia and China. Where the selection of countries to be discussed was seen in terms of the potential for CBM reserves in the world and the progress of CBM processing technology that has been implemented in those countries.

The data used were official data issued by relevant ministries in these countries, prospects for the world's energy transition, statistical data for companies engaged in energy, and several journals related to CBM and its utilization.

By comparing the constraints on exploration, production and utilization of CBM as a new source of energy, it is hoped that the existing problems related to $\mathrm{CBM}$ can be resolved immediately and the acceleration of CBM utilization can be carried out.

\subsection{DATA ANALYSIS AND DISCUSSION}

The Coal Bed Methane market has experienced healthy growth in recent years, and is expected to continue to grow due to the following factors [30]:

1. The emission of methane fuel is much lower than that produced from conventional fuels and coal mining, thus supporting the global green-house resolution program [13].

2. The increasing demand for sustainable fuels so that CBM is used to reduce dependence on conventional natural gas sources is expected to be the main driver of the North American market. Governments in various countries provide tax incentives to companies conducting these operations with the aim of increasing the energy mix used, which is again a big driving factor. The price of CBM is also lower than the price of other non-conventional natural gas, thereby increasing its market attractiveness [30].
3. Economic growth in Asia-Pacific has led to increase energy demand in the region, with China, India and Indonesia as the main contributors. Companies are attracted to invest in this region due to the large amount of unproven Coal Methane reserves in these countries [30].

There will be an increase in electricity demand by 3 times from 2018 with a plan to utilize renewable energy of $90 \%$ of the total world energy supply [31].

CBM is predicted to contribute $40.6 \%$ of the world's total electrical energy demand by 2050 [32]. With the total amount of on-site CBM reserves worldwide estimated to be between 3,500 and 95,000 Tcf (100 and 272 trillion $\mathrm{m} 3$ ), CBM is considered one of the largest fossil fuel sources in the world [33].

Table 3: CBM reserves in the world [33]

\begin{tabular}{cll}
\hline NO & COUNTRY & CBM potential \\
\hline 1 & Russia & $450-2.000 \mathrm{TCF}$ \\
2 & China & $700-1.270 \mathrm{TCF}$ \\
3 & United States & $500-1.500 \mathrm{TCF}$ \\
4 & Australia/New Zealand & $500-1.000 \mathrm{TCF}$ \\
5 & Canada & $360-460 \mathrm{TCF}$ \\
6 & Indonesia & $400-453 \mathrm{TCF}$ \\
7 & South Africa & $90-220 \mathrm{TCF}$ \\
8 & Western Europe & $200 \mathrm{TCF}$ \\
9 & Ukraine & $170 \mathrm{TCF}$ \\
10 & Turkey & $50-110 \mathrm{TCF}$ \\
11 & India & $70-90 \mathrm{TCF}$ \\
12 & Kazakhstan & $40-60 \mathrm{TCF}$ \\
13 & South America/Mexico & $50 \mathrm{TCF}$ \\
14 & Poland & $20-50 \mathrm{TCF}$ \\
\hline
\end{tabular}

In addition, developing countries are trying to get carbon credits by diverting interest in using CBM for electricity generation because CBM-fired power plants convert methane into water and carbon dioxide $\left(\mathrm{CO}_{2}\right)$ and further reduce greenhouse gas emissions significantly [34].

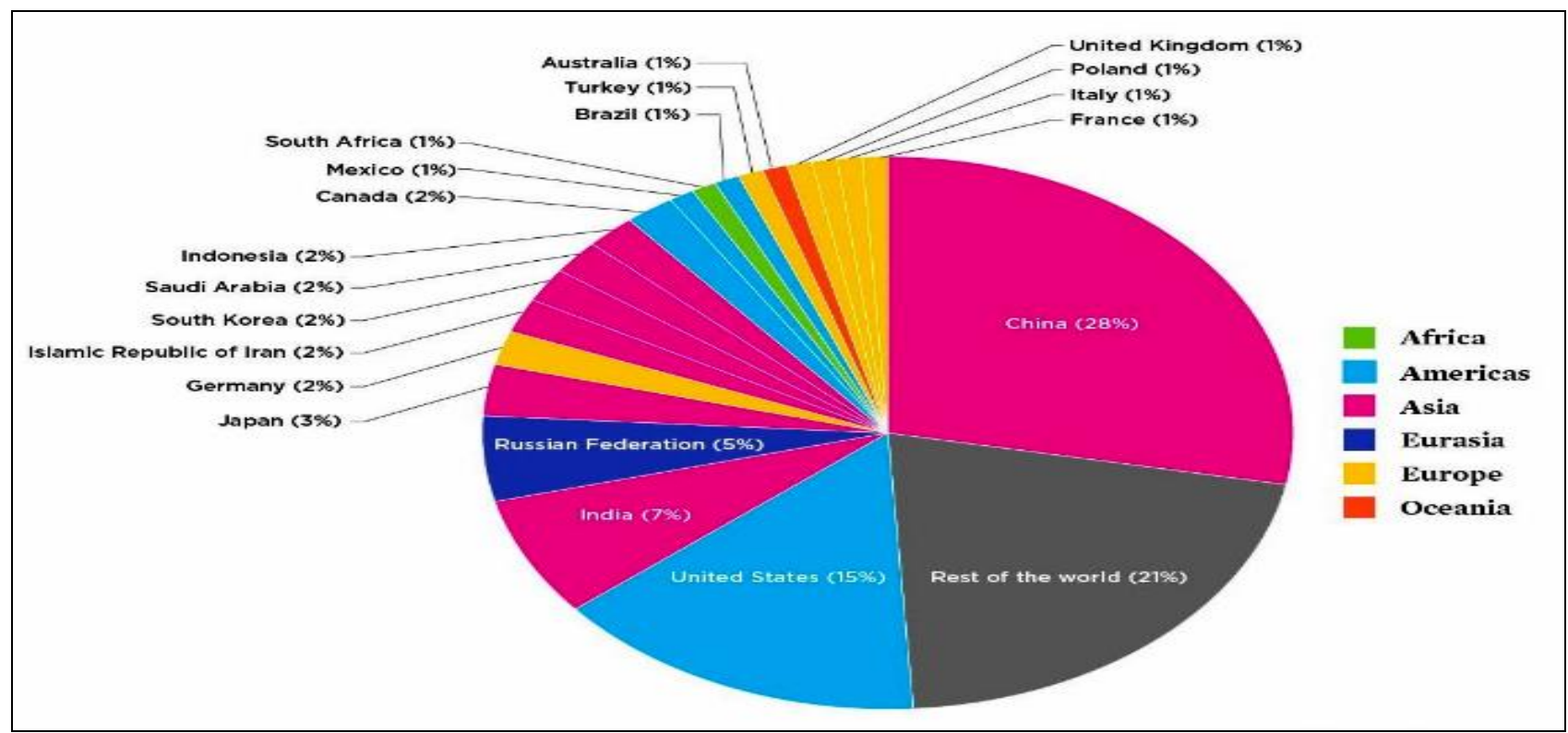

Figure 7: Countries share of $\mathrm{CO}_{2}$ Emissions [33] 
Increasing demand for CBM energy has caused countries in the world to compete to find CBM resources and improve CBM processing technology. Each country has constraints and challenges for the exploration and production of CBM, so it is necessary to conduct a comparative review to accelerate the utilization of CBM, especially in Indonesia [35].

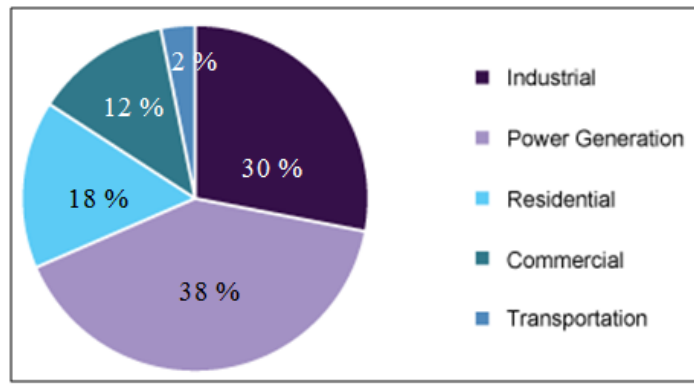

Figure 8: Utilization of CBM in the World [30]
The utilization of CBM is currently still dominated by power plants (38\%), industry (30\%), housing (18\%), commercial $(12 \%)$ and the remaining $2 \%$ for transportation in big cities of developed countries [30].

\subsection{Coal Bed Methane in Indonesia}

Energy consumption which always rises every year in Indonesia is not balanced with sufficient energy supply so that there is an imbalance in the energy where Indonesia is still very dependent on fossil energy (hydrocarbons) by $96 \%$ consisting of petroleum $48 \%$, gas $18 \%$ and coal $30 \%$ [36].

Meanwhile, for power plants, the demand for fossil fuels is $64 \%$, consisting of $56 \%$ Coal, $6 \%$ Oil and $2 \%$ Gas. The demand for gas in Indonesia in 2025 according to the gas balance in the National Gas Road Map published by the Ministry of Energy and Mineral Resources is estimated at $20 \%$ of the National Energy Mix (8248 BBTUD), while production is currently experiencing a decline so it is necessary to accelerate the utilization of New Energy [37].

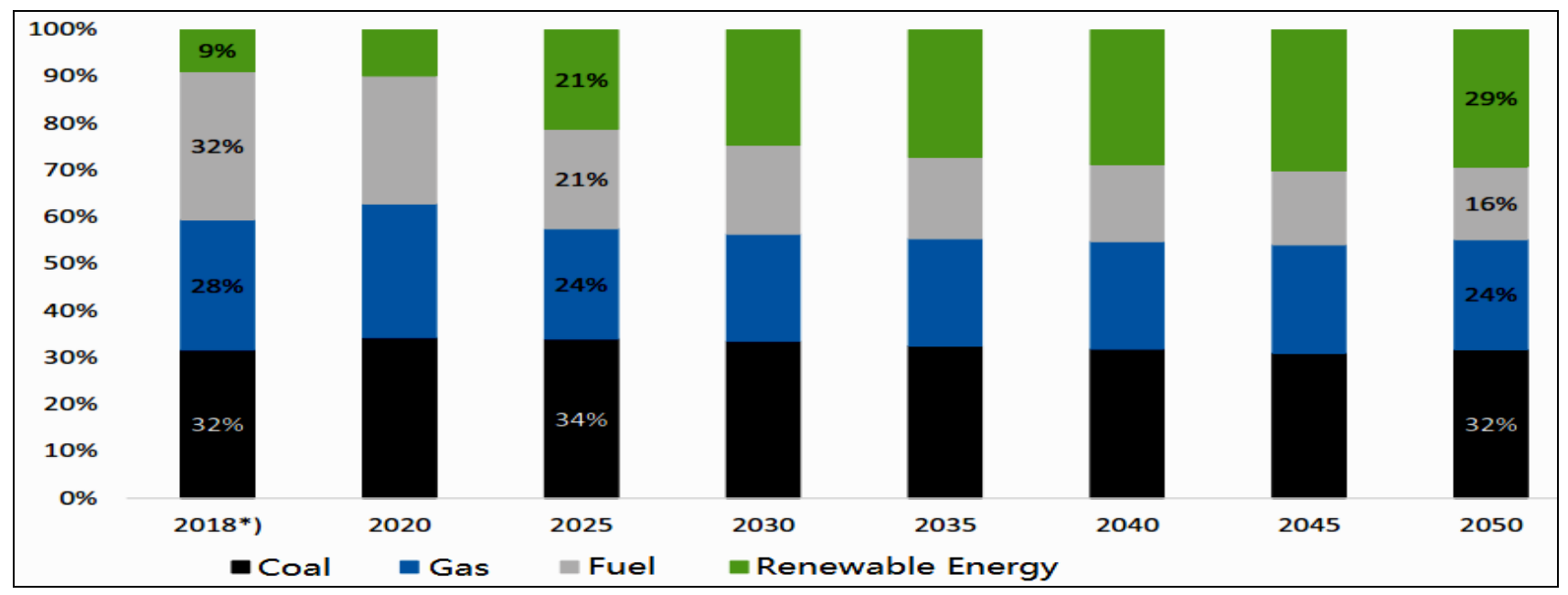

Figure 9: Indonesia's primary energy development [36]

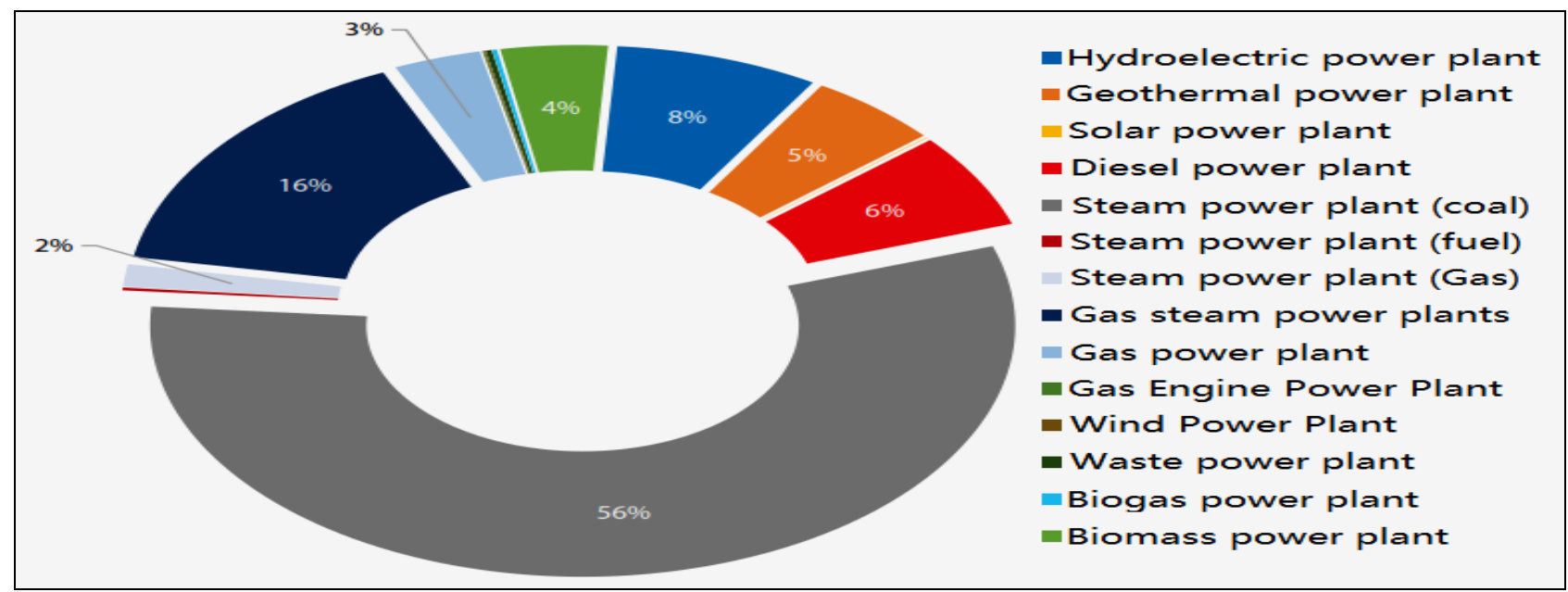

Figure 10: Indonesia's electricity production by energy type [36] 
Pursuant to the Indonesian Government Regulation (PP) Number 79 of 2014, it is stated that new energy is energy that comes from new sources of energy or from clean energy or even fossil energy but is produced by new technology.

This regulation is in line with research conducted in 2003 regarding methane gas and is set forth in the form of a pilot project of 5 (five) Coal Bed Methane (CBM) test wells in Rambutan Field, Muara Enim Regency, South Sumatra with a depth of 600-1000 meters using the artificial lift method. using a sucker rod pump (SRP) with the conclusion that the overall potential of these 5 wells is $5.5 \times 106 \mathrm{MSCF}$ and can be produced for 20 years with a daily maximum capacity of $1120 \mathrm{MSCF} /$ day [38]

This testing stage is based on the results of the 2003 CBM resource assessment which estimates the potential for CBM in Indonesia to be $453 \mathrm{TCF}$ spread over 11 coal basins (basins), one of which is the South Sumatra basin of 180 TCF. In 2004, the drilling of the first CBM well in Indonesia was started. In line with that, an environmental feasibility study and a draft Ministerial Decree on CBM were carried out. In 2005-2006 period, 4 CBM wells were drilled with a depth of 600-1000 meters with the results of the test wells in accordance with the assessment that has been carried out so that in 2006 the Minister of Energy and Mineral Resources Regulation No. 33 of 2006 concerning Coal Methane Concession (CBM) was issued based on the results of a CBM regulation which started in 2003 [37].

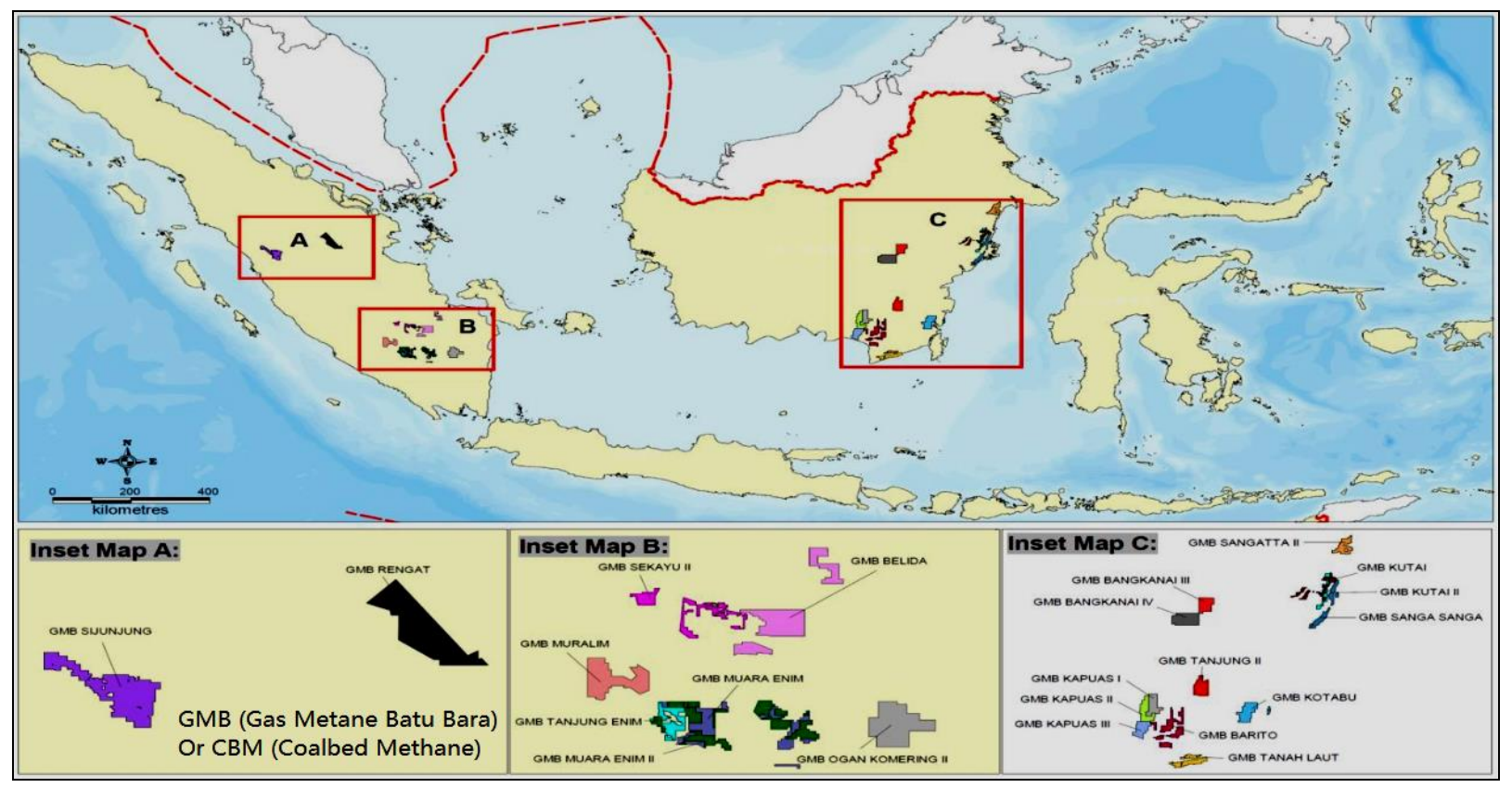

Figure 11: CBM exploration in Indonesia [35].

Tabel 4 : CBM Potential Basin Map in Indonesia [39]

\begin{tabular}{lc}
\hline Basin & Potential (TCF) \\
\hline Central Sumatera & 52,5 \\
Ombilin & 0,5 \\
South Sumatera & 183,0 \\
Bengkulu & 3,6 \\
Jatibarang & 0,8 \\
North Tarakan & 17,5 \\
Berau & 8,4 \\
Kutai & 80,4 \\
Barito & 101,6 \\
Pasir/Asem & 3,0 \\
Southwest Sulawesi & 2,0 \\
\hline TOTAL & 453,3 \\
\hline
\end{tabular}

Figure 11 shows a map of a basin with a very large CBM potential in Indonesia with a total of 453.3 TCF with a total of 11 proven basins so that Indonesia ranks 6th in the world (table 3). Power plants with high speed diesel (HSD) require a cost of 2000/kwh while the use of CBM costs 700-1000/kwh [39]. In the example of the Sanga-Sanga power plant, Kutai
Kertanegara Regency, East Kalimantan, where with the use of $\mathrm{CBM}$, the price of electricity can be reduced to IDR $1150 / \mathrm{kwh}$ compared to the use of diesel fuel of IDR 2700/kwh [40]. To generate $1 \mathrm{MW}$ of electricity, $0.25 \mathrm{mmscfd}$ of CBM is needed with an investment cost for a gas engine of US\$ 1 million/MW [40].

CBM contained in Indonesian coal has the characteristics of lignite rank (carbon content $40-55$ percent)-anthracite (carbon content $86-98$ percent, moisture content 8 percent), with a layer thickness of tens of meters in one layer formation and potential CBM at a depth of $300-1000$ meters with an average methane content of $100 \mathrm{scf} / \mathrm{ton}$ in the seam. To support the development of CBM, the government through the Minister of Energy and Mineral Resources has issued a road map of CBM development in Indonesia until 2025 (figure 12) and issued the Minister of Energy and Mineral Resources Regulation number 033 of 2006 concerning the Concession of Coal Methane Gas (CBM) but the regulation still needs to be studied and evaluated to avoid conflicts, especially in the section on profit sharing arrangements for CBM and coal exploitation, waste management and forms of cooperation. 


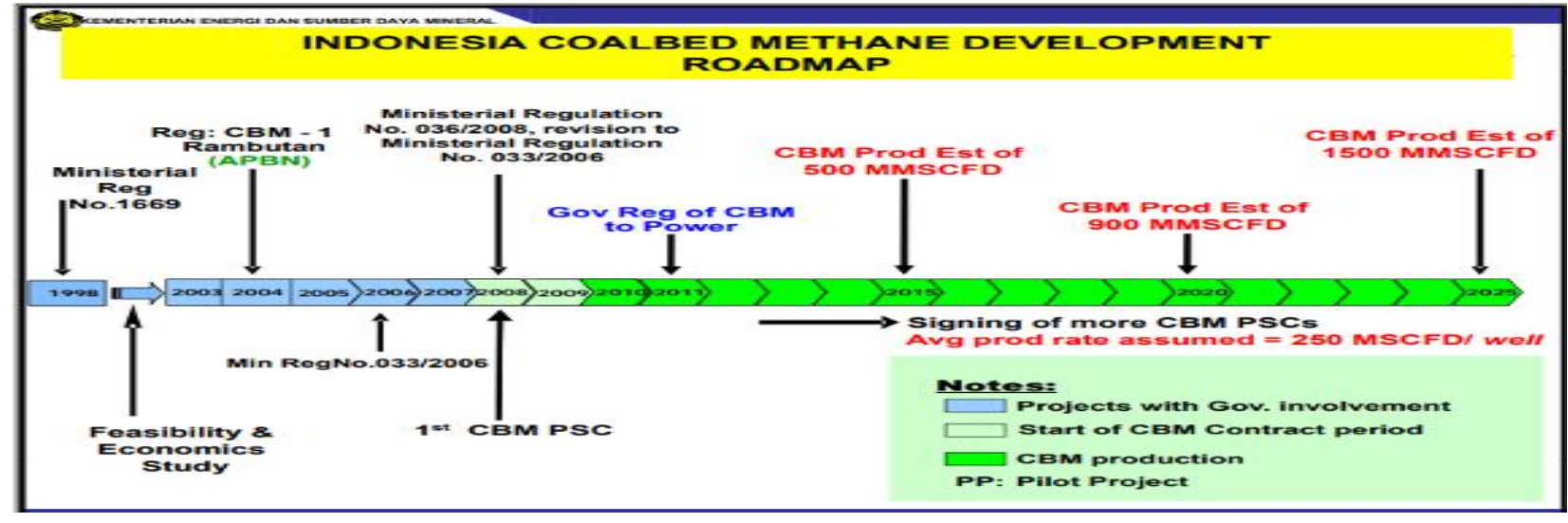

Figure 12: Road map of CBM development plans in Indonesia [20]

Indonesia has basins with large methane content in several areas (fig 12) with a high $\mathrm{CH} 4$ carbon chain content with several advantages and disadvantages so that it is considered necessary for government intervention to accelerate the use of $\mathrm{CBM}$ in Indonesia.

Indonesian CBM has a good quality of gas content including the composition and thickness of $\mathrm{CH} 4$. In addition, most of Indonesian CBM is in a saturated condition so it takes a short time for the dewatering process before the gas is released [35]. However, CBM owned by Indonesia has a small permeability (pores) so it is necessary to carry out a stimulus such as cracking to release gas maximally.
Coal is brittle, so mine construction formations are prone to collapse [35].

From the results of the study of the quantity and quality of CBM in Indonesia, the Indonesian National Energy Policy [KEN] issued the General National Energy Plan [37] for the energy mix of CBM utilization in 2025 of $46 \mathrm{mmscfd}$ and 2050 of 576.3 mmscfd [40].

The ease of development provided by the government has not been effective until now because of the 54 working areas (WK) from 2008-2012 only 22 CBM CAs (1 Tanjung Enim CA is currently in the POD process) are active and 32 CBM CAs have been terminated [38].

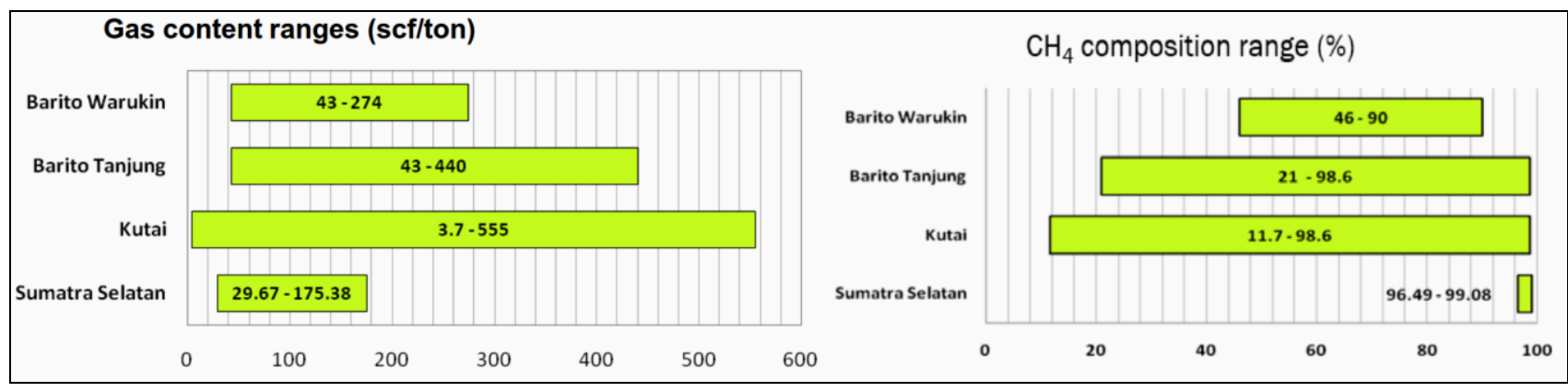

Figure 13. Gas content and composition of $\mathrm{CH} 4$ [35]

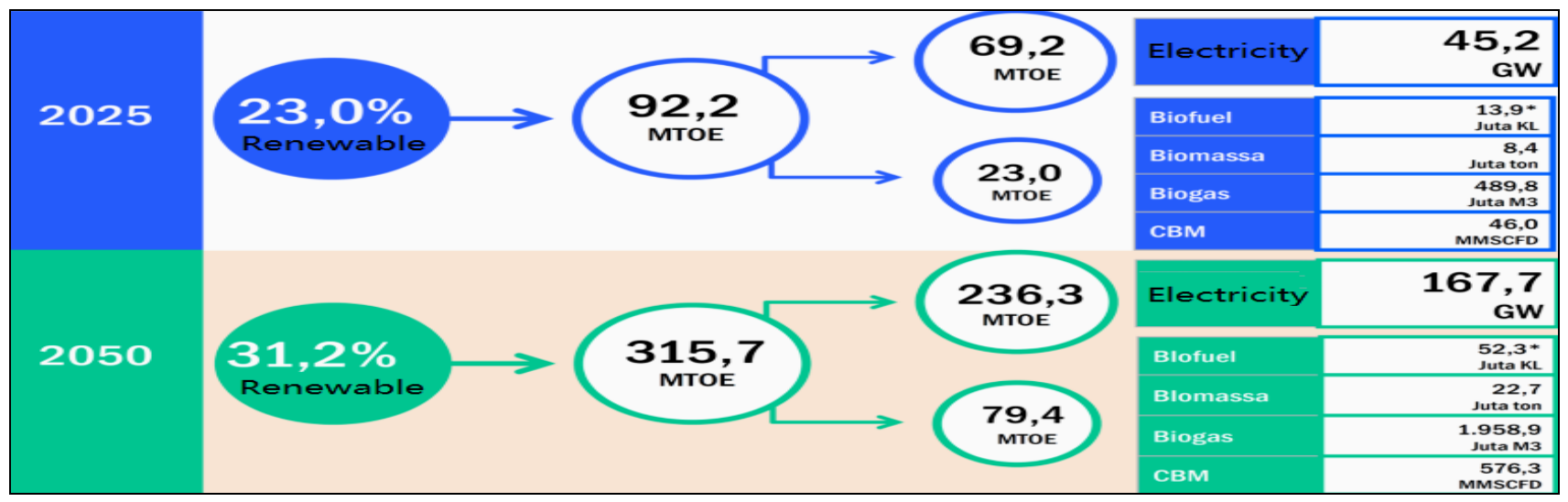

Figure 14: Target for CBM development as an NRE mix [35] 
To meet the target of the CBM energy mix (Figure 7) the Indonesian government through the improvement of the Minister of Energy and Mineral Resources Regulation number 36 of 2008 provides convenience for CBM development efforts, namely:

1. Profit sharing is more profitable for contractors than conventional gas.

2. More flexible Plan of Development (POD) terms.

3. Handling production before POD.

4. Smaller working area allowance (up to 90 percent).

The huge potential of CBM currently cannot be optimally produced in Indonesia due to [47]:

1. Problems with licensing regulations across ministries and agencies.

2. Land acquisition issues.

3. Production facilities and piping from CBM wells.

4. Large investment value with uncertain prospects for return on investment (internal rate of return/IRR).

5. Small production profit.

6. Technology development that is not yet optimal.

7. CBM prices are still influenced by world oil prices where CBM will have economic value if world oil prices are above US $\$ 100 /$ barrel [38].

8. The ever-changing fluctuations in coal prices.

From the aforementioned problems, it is important to conduct a thorough evaluation and follow-up so that the clean energy mix target from CBM can be achieved.

Oil and gas regulations are not fit for CBM production. (Law number 22/2001 on oil and gas, Government Regulation number 35/2004 on upstream oil and gas activities, Minister of Energy and Mineral Resources Regulation number 35/2008 on procedures for stipulating and offering work areas of oil and gas, Minister of Energy and Mineral Resources Regulation number 36/2008 on CBM exploitation, Minister of Energy and Mineral Resources Regulation number 05/2012 on procedures for stipulating and offerring work areas of unconventional oil and gas).

Based on the aforementioned condition, the Government needs to [35] :

1. Improve the regulation of mineral and coal (Minerba).

2. Accelerate the process of proved CBM explorationproduction in productive areas. ENHANCE exploration points in the sweet spot area.

3. Research and test completion and operation methods to determine the right stimulation in order to achieve lowcost operation so that the price of CBM production is not influenced by world oil prices and coal prices.

\subsection{Development of Coal Bed Methane in Russia}

From 1990 to 2019, the installed power generation capacity in the Russian federation had increased by $27.7 \%$ and there had been an increase in electricity consumption by $17.8 \%$ from 2005 to 2018 which is used for the public, construction, mining, industrial sectors, agriculture, transportation and others with a reduction in electricity grid losses of $8.4 \%$ [41]. The high percentage of increase in energy demand in the Russian Federation has led to a high demand for fuel for power generation, which is estimated to be dominated by gas fuels, including non-conventional gas fuels until 2040.

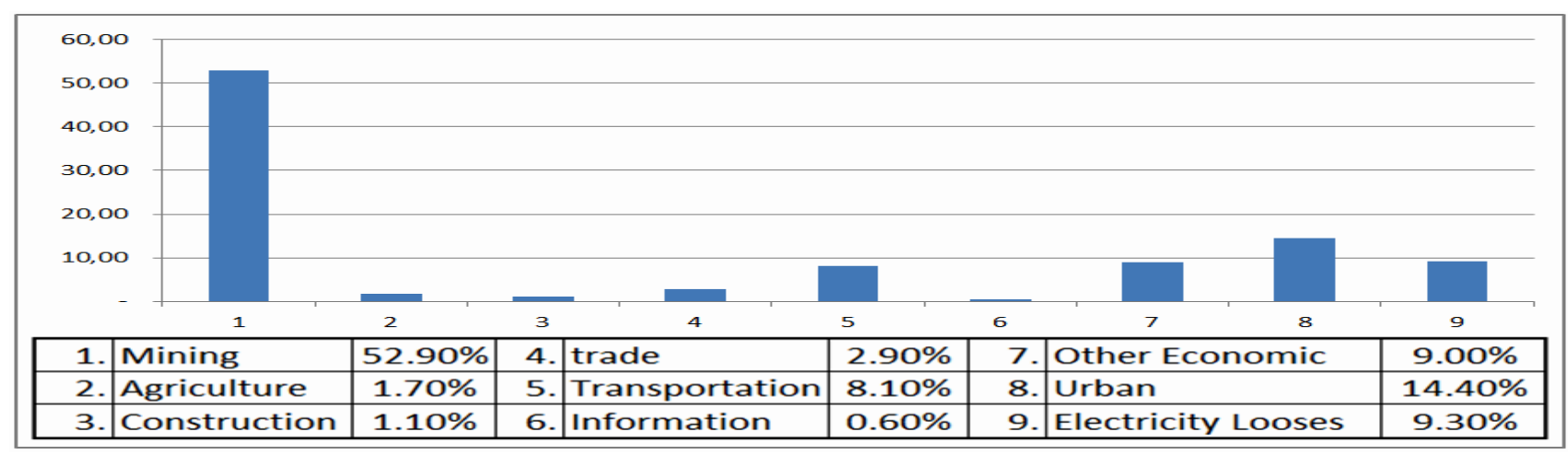

Figure 15: Electricity consumption per sector in Russian Federation [42]

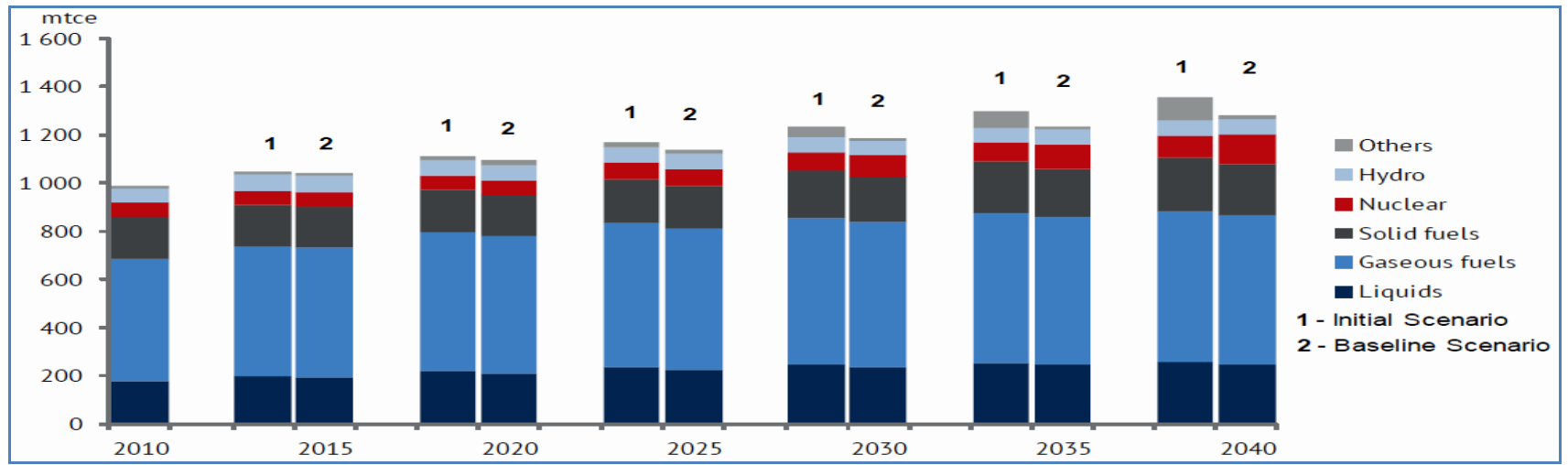

Figure 16: Energy consumption in the Russian Federation by fuel types [41] 


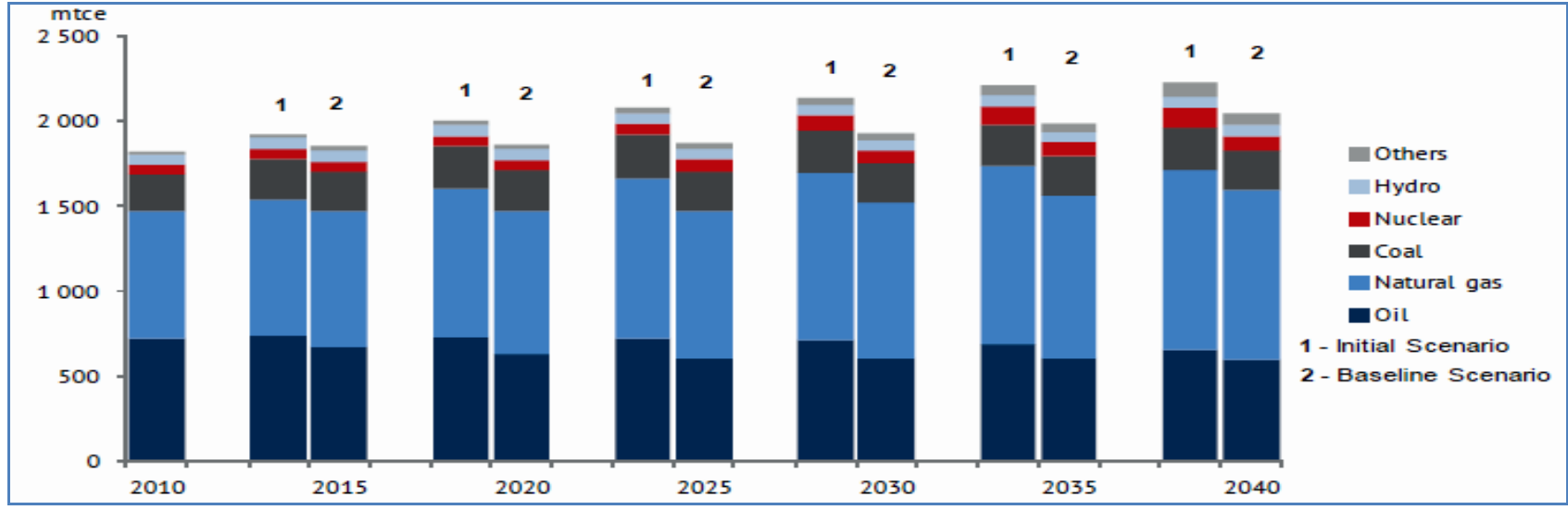

Figure 17: Primary energy production in the Russian Federation [41]

As one of the countries with the largest natural energy reserves, the primary energy production in Russia is still dominated by natural gas and oil, while Russia still has other energy sources, so the Russian government is trying to add to its energy mix as alternative energy with large reserves.

With large coal reserves, Russia plays an important role in research and development of coal mine methane (CBM) projects coupled with the support of the Russian government in 2009 on the increase in power generation, the development of CBM in Russia is not only to increase power generation but also to reduce greenhouse pollution. Where on 23 September 2019, Russia was the fourth largest emitter of greenhouse gases in the world (ratification of the Paris Agreement on Climate Change) [41].

The development of CBM projects in Russia is also supported by the existence of the world's largest pipeline construction from East Russia to all European countries. In addition, Russia is a strong natural gas market in Europe and Asia, coupled with rising domestic natural gas prices, can help push the project exploration and utilization of CBM in Russia [42][43]. CBM known as Coal Mine Methane (CMM) is owned by Russia as many as 11 basins with a total potential of 83,700 Cubic Meter Banks [43].

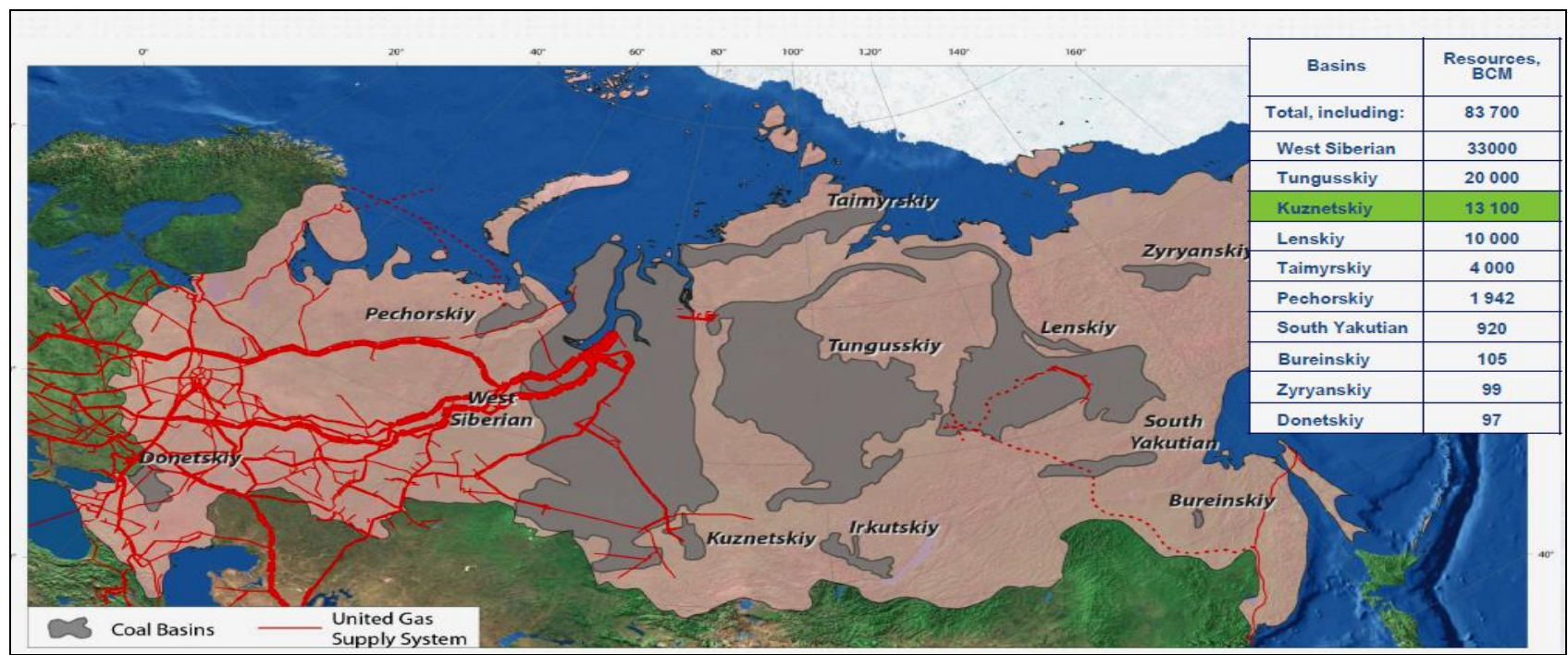

Figure 18: Map of proven coal fields and CBM gas supply lines in Russia [43]

In addition to having coal fields with proven CBM content, Russia is still conducting research to find other sources of reserves (Figure 18).

The smallest CBM field area is in the Talda Field with an area of $74 \mathrm{~km} 2$ with a potential CBM of $88.4 \mathrm{BCM}$ with a total of 20 test wells and a production of $30 \mathrm{MMcum} / \mathrm{year}$ for power stations of 2-10 MW (figure 18). The current use of CBM is for boilers and power plants, autonomous gas filling compressor stations, mini LNG plans (1 ton/hour), industrial and commercial customers as well as homes with energy details as follows [43]

1. Coal accounts for 13.2 percent of Russia's total primary energy consumption.

2. Coal production increased 43.7 percent between 2007 and 2017.

3. Russia's power generation in 2017 was divided between natural gas (52.3 percent), oil (21.9 percent), coal (13.2 percent), nuclear (6.5 percent), and hydroelectric power $(5,9$ percent $)[3]$. 


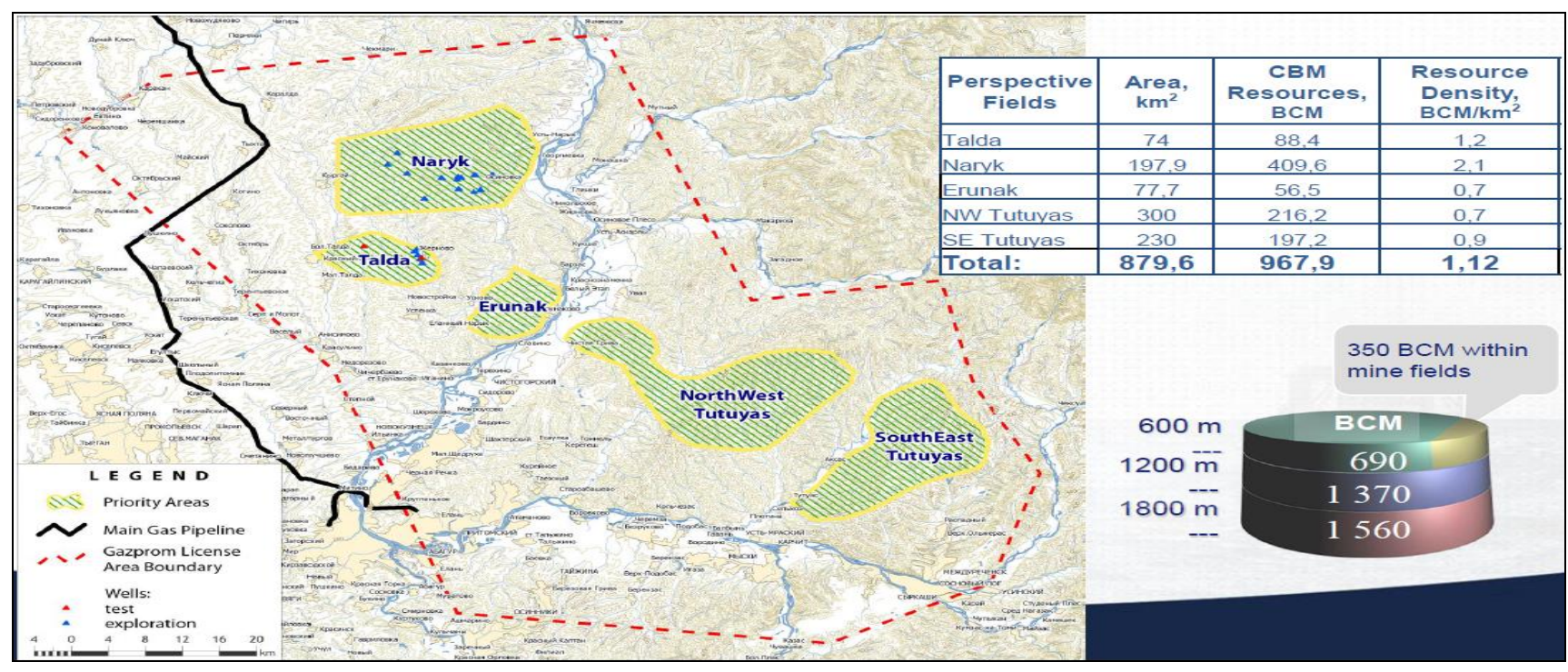

Figure 19: Projected map of CBM development plans in Russia [43]

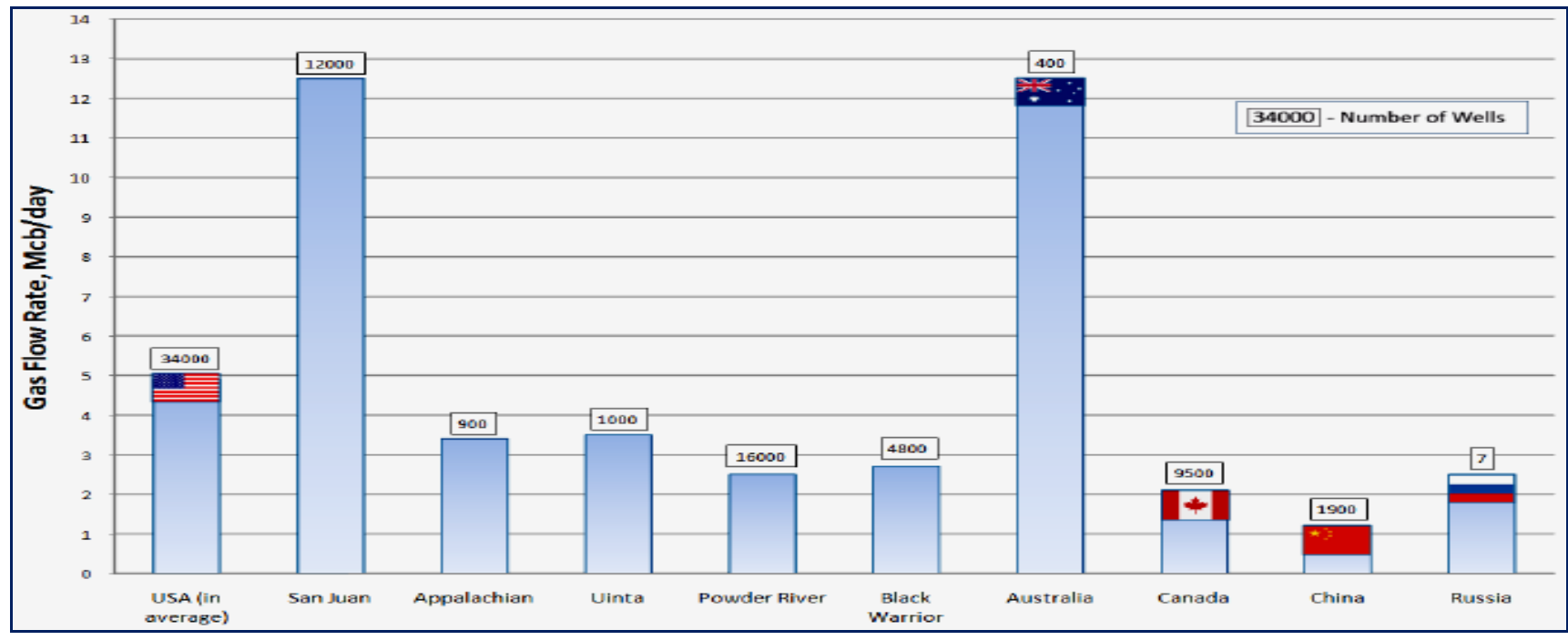

Figure 20: Number of CBM production wells in the World [43]

In 2015, Russia had six operational CBM utilization projects for power generation or boiler fuel. Two additional CBM projects were under development [45].

The results of the Feasibility Study (FS) stated that the gas content increased by 15 cubic meters per tonne (m3/ton) at a depth of 250 meters and $30 \mathrm{~m} 3 / \mathrm{ton}$, at a depth of 650 meters with CBM quality suitable for power plants. [45].

The problem in the exploration process is that the amount of water that exceeds the maximum requirement has caused 43 mines in the Kuzbass Basin to be inundated, making the methane production operation project difficult or impossible to continue [43].

In 2010-2013, exploration work and test wells had been carried out from 30 exploration wells and then in 2013-2014 the preparation and verification phase of Feasibility Study (FS) had been carried out with a total planned development well of 1000 and a production target of 1-1.5 BCM per year.
Russia with the largest CBM reserves in the world only has 7 wells that supply gas for large power plants (>100 MW) due to the majority of CBM reserves being in remote and undeveloped areas and the slow development of CBM because [46]:

1. CBM is owned by the state with three licenses that are the contractor's obligation, namely exploration, production, and joint licenses.

2. CBM must compete economically with large, domestic, and cheap proven gas reserves.

3. The Russian government maintains a large supply of gas at a low selling price, making it difficult for $\mathrm{CBM}$ projects to achieve financial viability. However, domestic natural gas prices have increased 16 percent since 2013, making the project more viable [43].

4. The challenge of developing an economical technology for the extraction of CBM from saturated coal seams with low permeability. 
5. Natural gas infrastructure and markets are within 20 to 100 kilometers of CBM production areas [46].

6. Electricity production projects utilizing CBM have a return on investment of 25 percent [47].

Due to the above problems, the Russian government is currently accelerating the use of CBM to attract investors by:

1. Operating tax exemption.

2. Income tax reduction.

3. Royalty exemption.

4. Research development of production technology with low permeability field.

5. Lowering hydrocarbon recovery costs.

\subsection{Development of Coalbed Methane in United States of America}

The United States uses and produces a wide variety of energy sources and types, which can be grouped into general categories such as primary and secondary fuels, renewable and non-renewable, and fossil fuels.
Primary energy sources include fossil fuels (petroleum, natural gas, and coal), nuclear energy, and renewable energy sources. Electricity is a secondary energy source that is generated from primary energy sources [4].

In 2020, the total US primary energy consumption was equivalent to approximately $92,943,042,000,000,000 \mathrm{Btu}$, or approximately 93 quadrillion Btu [48].

In 2020, the electric power sector accounted for approximately $96 \%$ of total US utility-scale power generation, almost all of which was sold to other sectors.

The energy sources used by each sector vary widely. For example, by 2020 , petroleum wpuld provide about $90 \%$ of the energy consumption of the transportation sector, but only $1 \%$ of the primary energy use of the electric power sector.

Projected energy consumption is estimated that there are 700 tcf of methane gas in the conterminous layer of the United States with a proven potential of around 100 tcf and accounts for 7.5 percent of the total United States natural gas production which is used for electricity generation and domestic gas utilization [4].

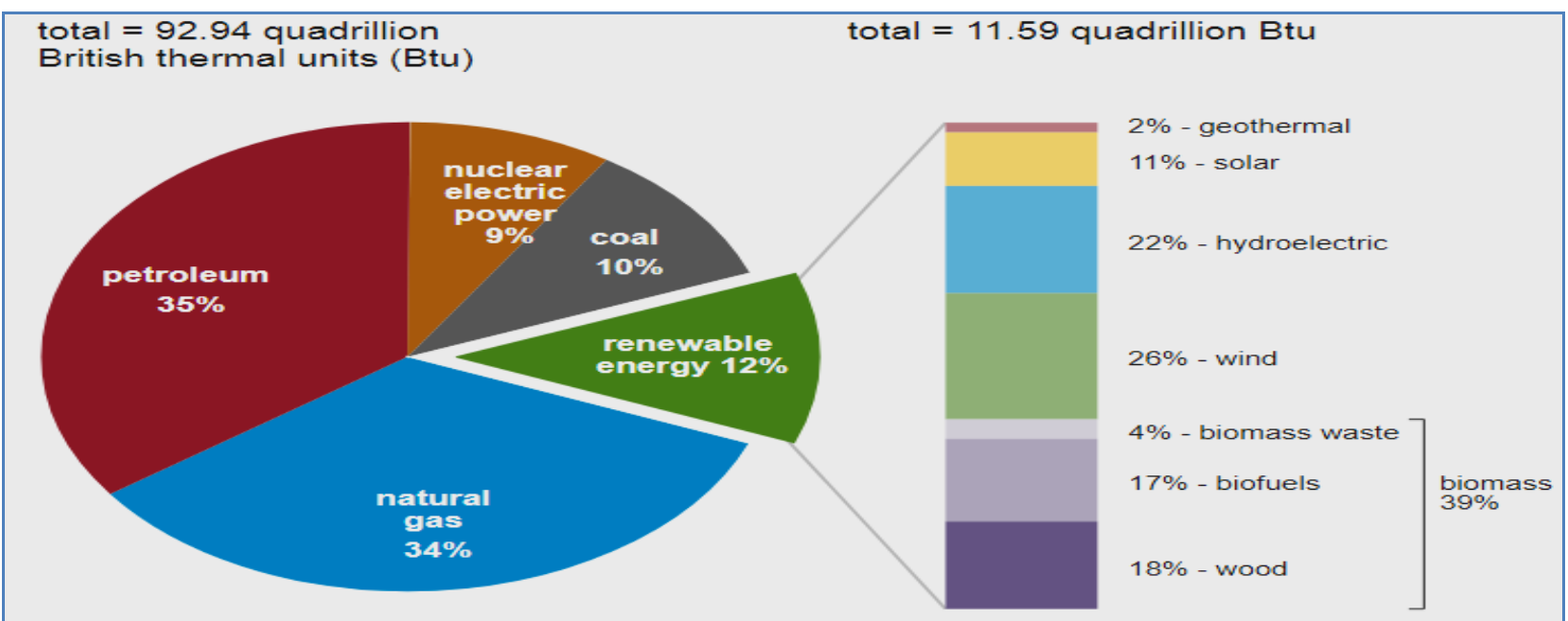

Figure 21: US Energy Consumption by energy sources [4]

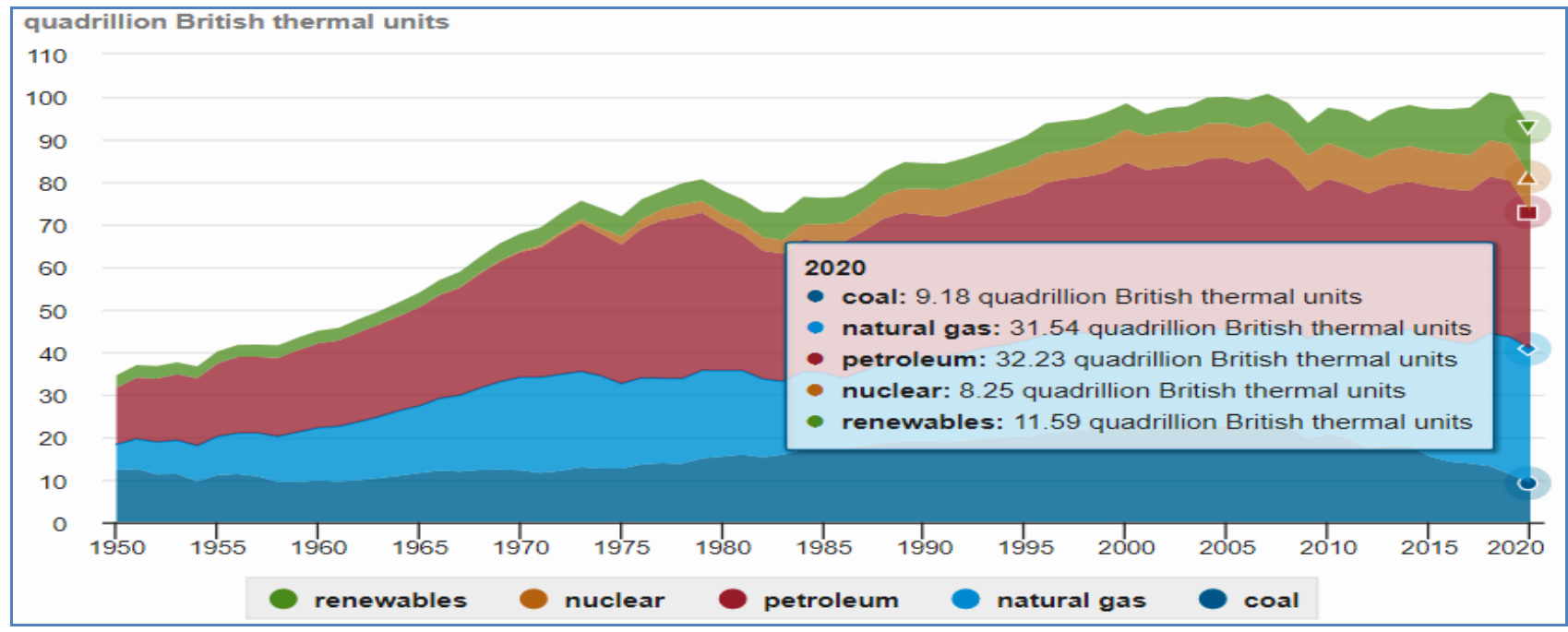

Figure 22: US Energy Consumption by energy sources [4] 


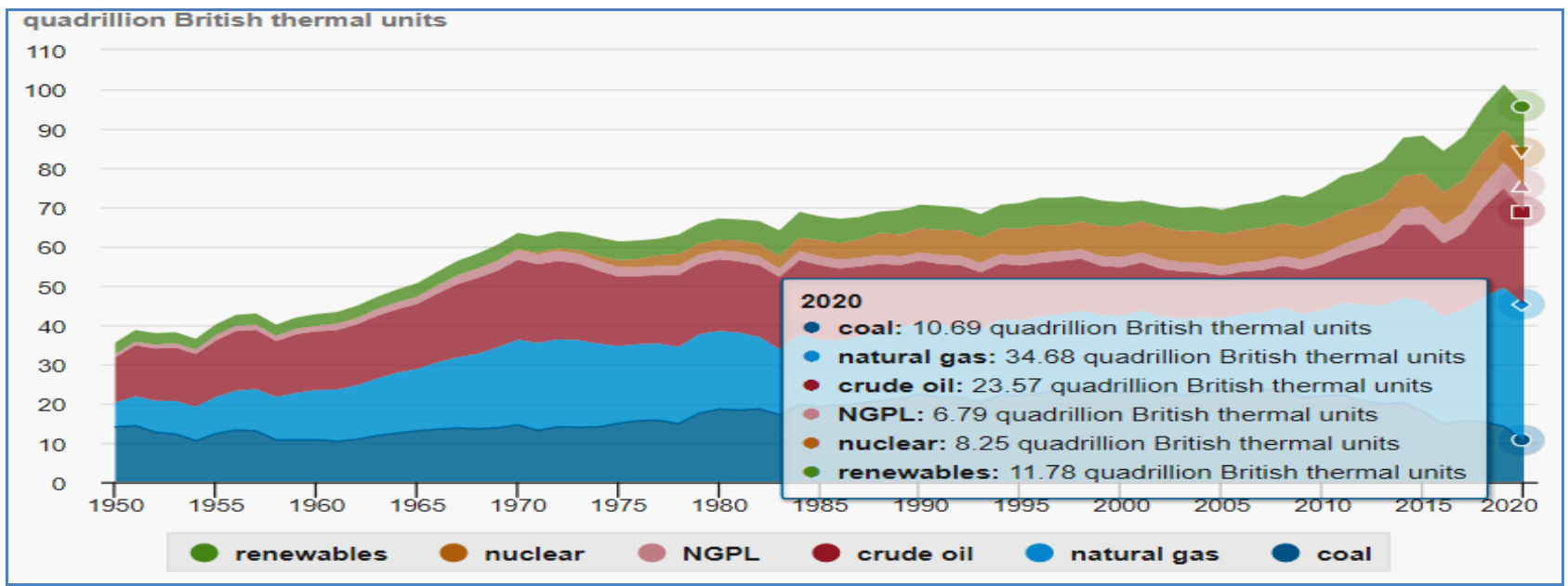

Figure 23: US Energy Production by energy sources [4]

Table 7: Coalbed Methane Consumption and Production in the US [4]

\begin{tabular}{|c|c|c|c|c|c|c|c|c|c|c|}
\hline \multirow[b]{2}{*}{ Decade } & \multirow[b]{2}{*}{ Year-0 } & \multirow[b]{2}{*}{ Year-1 } & \multirow[b]{2}{*}{ Year-2 } & \multicolumn{7}{|c|}{ U.S. Coalbed Methane Production (Billion Cubic Feet) } \\
\hline & & & & Year-3 & Year-4 & Year-5 & Year-6 & Year-7 & Year-8 & Year-9 \\
\hline 1980 's & & & & & & & & & & 91 \\
\hline 1990 's & 196 & 348 & 539 & 752 & 851 & 956 & 1,003 & 1,090 & 1,194 & 1,252 \\
\hline 2000's & 1,379 & 1,562 & 1,614 & 1,600 & 1,720 & 1,732 & 1,758 & 1,753 & 1,966 & 1,914 \\
\hline 2010's & 1,886 & 1,763 & 1,655 & 1,466 & 1,404 & 1,269 & 1,020 & 980 & W & W \\
\hline $\begin{array}{l}-=\text { No Data R } \\
\text { Release Date } \\
\text { Next Release }\end{array}$ & $\begin{array}{l}\text {; }--=N \\
021 \\
2 / 20 / 20\end{array}$ & plicable & $A=$ Not & ble; W & theld t & id disc & of indi & 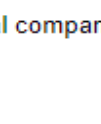 & & \\
\hline
\end{tabular}

In 2012, a 3-megawatt CBM power plant was built in Somerset, Colorado at the Elk Creek Oxbow Carbon Mine. The success of coal bed methane (CBM) in North America is due to a number of factors by chance the discovery of a gasrich coal seam with good and elongated porosity/permeability characteristics, strong gas prices, dense distribution network, and little competition with declining conventional gas production and geological conditions [50].

Research in the field of CBM utilization development design and the accuracy of the potential of the CBM layer was carried out by the U.S. Geological Survey (USGS) to obtain more economical exploration and production technology [49].

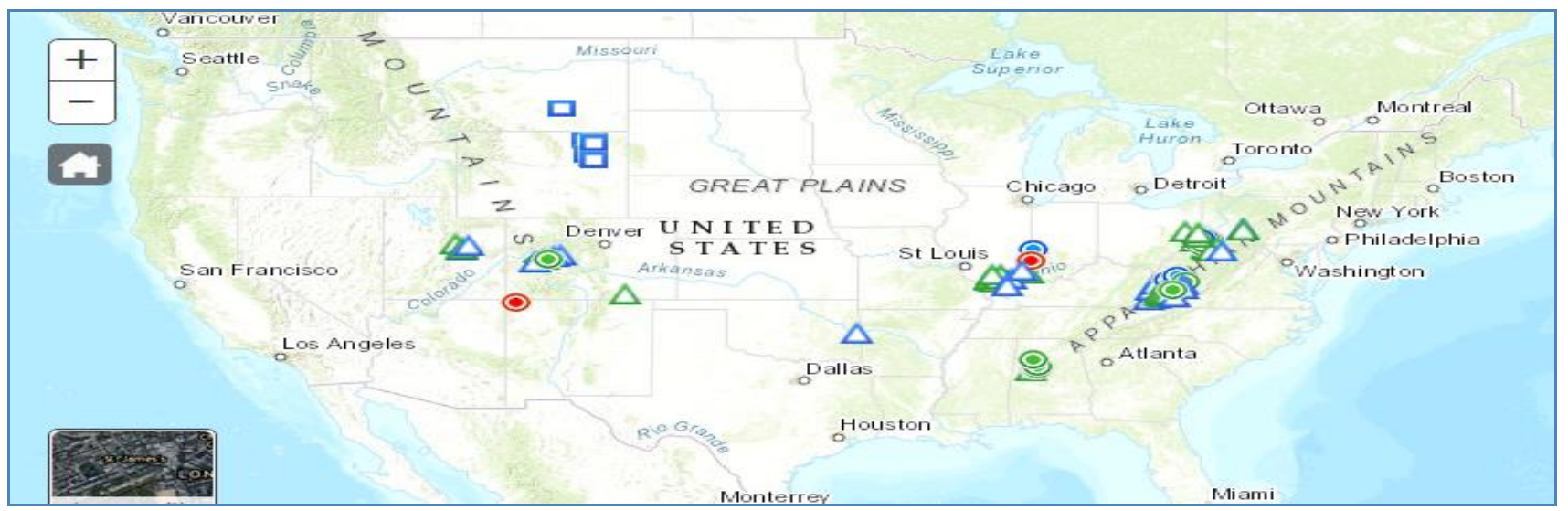

Figure 24: Map of coal and CBM fields in America [49] 


\section{U.S. coal bed methane market size, by application, 2016 - 2027 (USD Million)}

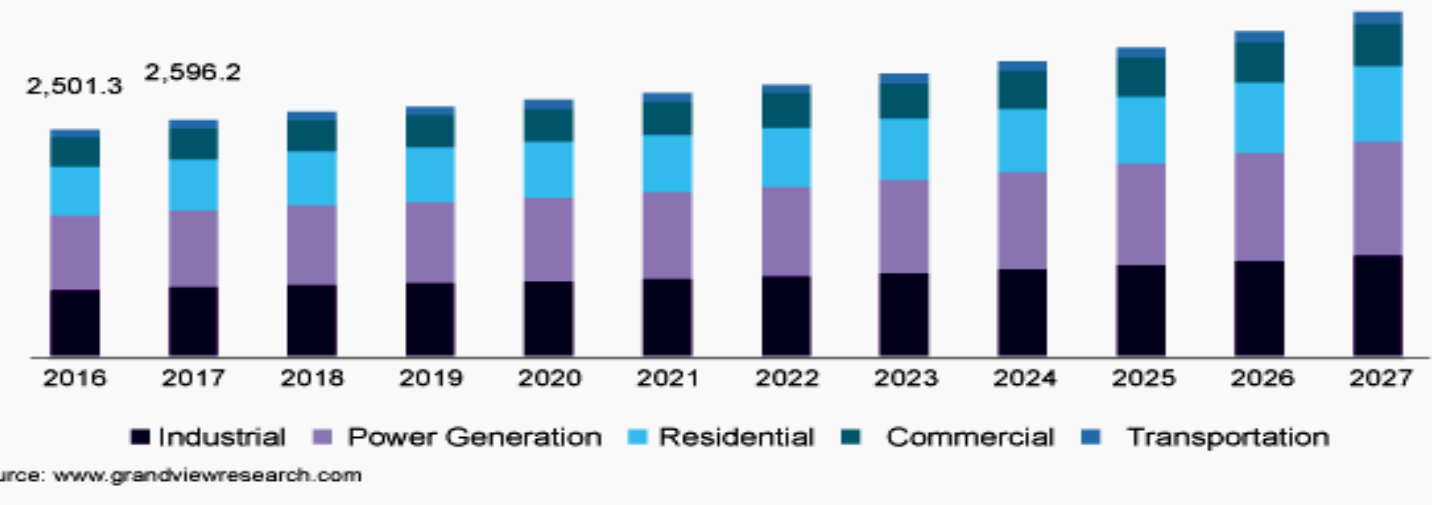

Figure 25: CBM Market in US [49]

U.S. The Geological Survey (USGS) is tasked with conducting research that provides information on the potential, problems and development of CBM as the United States National Energy's energy mix, namely by establishing a detailed development model and characteristics of the evolution of methane gas in coal seams in the highlands and valleys as well as developing ways to CBM resource assessment [49].

As a natural gas well, most coal seam methane licensing and regulation is carried out by state governments. The main problems of CBM in the US are environmental problems and the handling of produced water and the dewatering process so that federal regulations apply to handling CBM produced water i.e. if the water is discharged into surface runoff, it must obtain a permit from the federal state and if the water is discharged by underground injection using a Class Drain Well II got permission from the state [4].

The environmental impact of CBM development is regulated by federal government agencies both during the licensing and operating processes, namely building permits for roads, pipelines and buildings, obtaining wastewater disposal (produced water) permits, and compiling an Environmental Impact Statement [33].

\subsection{Development of Coalbed Methane in Australia}

A very significant increase in energy consumption in 20182019 in all sectors in Australia such as energy consumption increased by $1 \%$, electrical energy from: coal $56 \%$, petroleum $39 \%$, natural gas $36 \%$ causing the government to encourage the use of other energy mixes which is available in very large reserves in Australia [51].

Australia's energy consumption increased 1 percent in 2018-2019 to reach 6,196 penta joules $(1 \mathrm{PJ}=22,288 \mathrm{GWH})$ with energy growth in 2018-19 of 37 penta joules [52]. The large energy consumption and GDP that always increases significantly are not supported by energy productivity, but energy intensity as a measure of energy inefficiency decreases linearly every year. (Figure 16) [53].

Total energy consumption of 6,196 petajoules $(278 \mathrm{GWH})$ is still dominated by oil (1,402 petajoules), coal $(1,301$ petajoules), gas (1,592 peta joules) and renewable energy (399 peta joules).

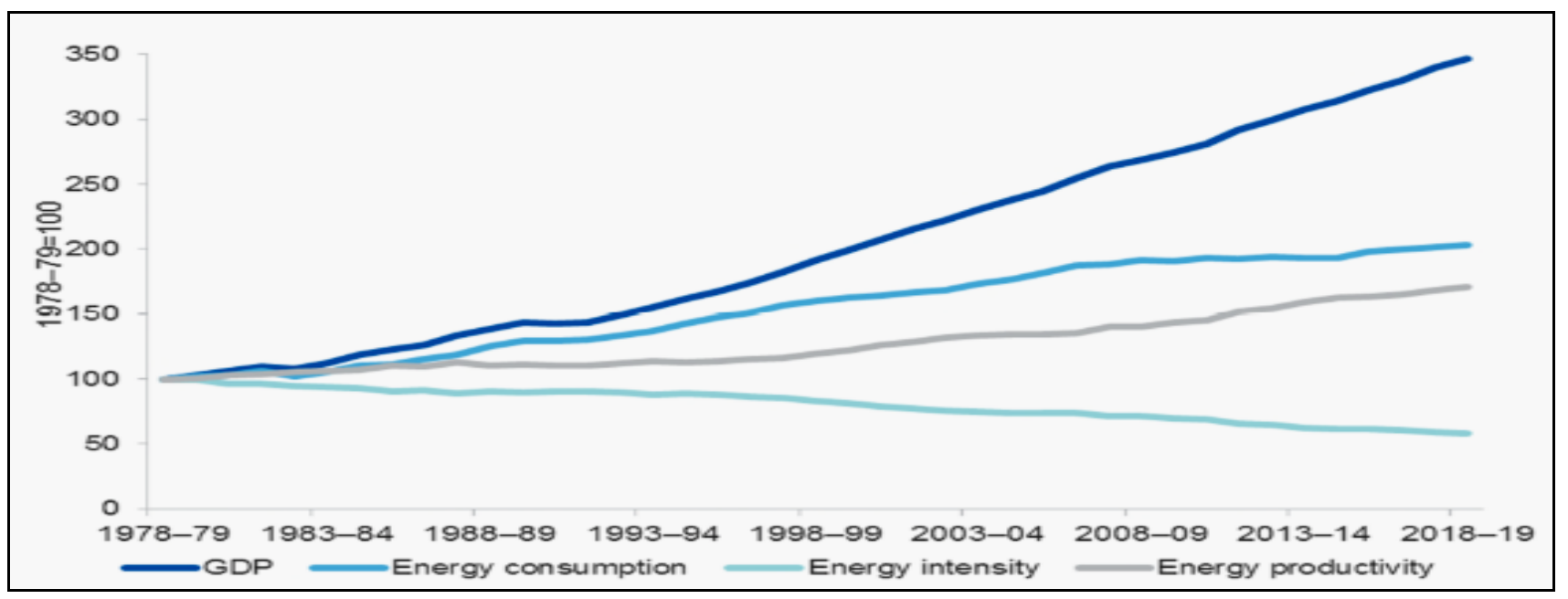

Figure 26: Energy Consumption vs Energy Productivity in Australia [53] 


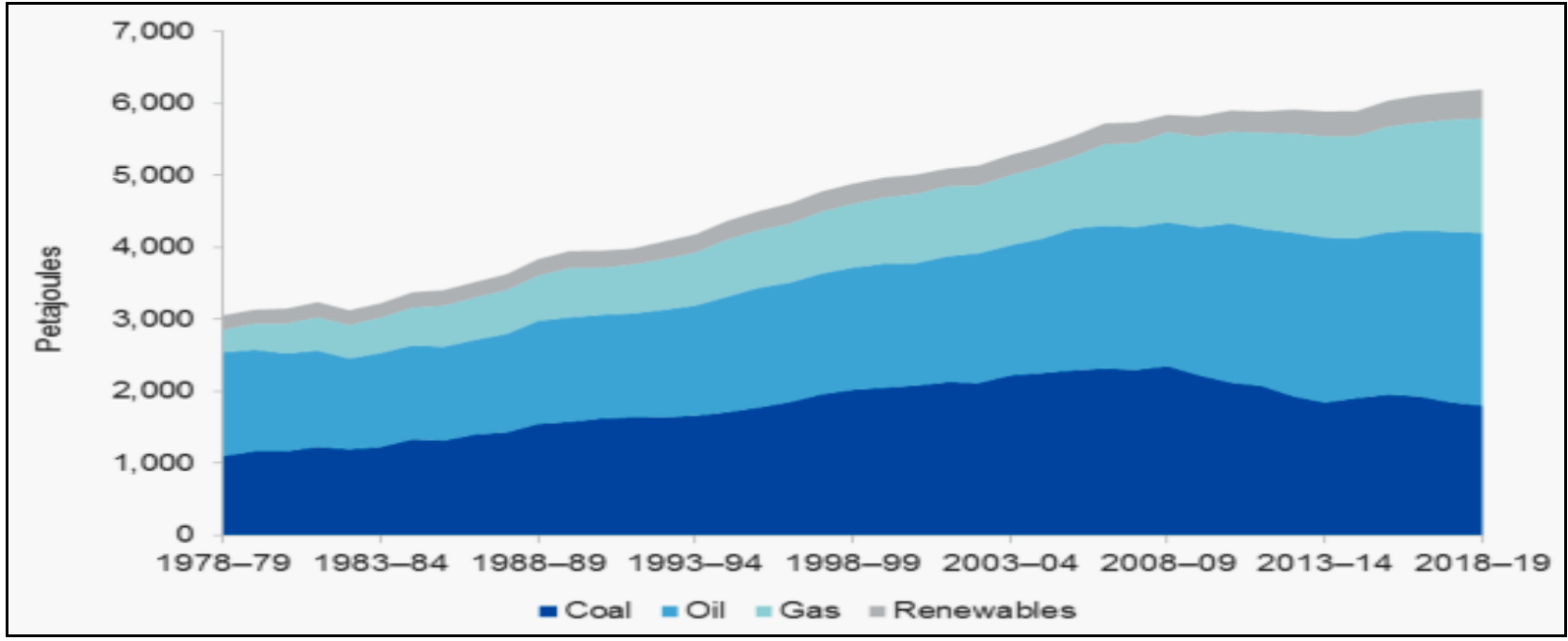

Figure 27: Energy Consumption by fuel types in Australia [53]

The large amount of energy reserves is still dominated by large coal production so that the amount of the energy mix does not vary. (Australia Energy resources, 2020) The largest power plant fuels are petroleum $(209,639 \mathrm{GWH})$ and black coal (116.356 GHW).

In Australia Coalbed Methane (CBM), called Coal Seam Gas (CSG) or Coal Seam Methane (CSM), where this new energy is targeted to become a significant energy contributor need. Australia has about 30 coal-bearing basins, most of them Permian and Mesozoic in age.

Australian coal seams contain high volumes of methane gas of up to $25 \mathrm{~m} 3$ per tons. Australia began producing CBM in 1988 but it was not until 2006 that commercial production of CBM began in the state of Queensland. Australia has total CBM reserves of around 300 to $500 \mathrm{Tcf}$ (8.6 to 14.3 trillion m3) [53].

In Australia, CBM is produced as clean energy and of very good quality so that CBM is growing rapidly along with the discovery of large CBM resources, thus encouraging a reduction in coal seam gas production costs and cleare state regulations for $\mathrm{CBM}$ contractors, this is due to the exploration method and the production of CBM that does not damage the environment and the produced water which is reprocessed into clean water and partly used to clean coal from attached sulfur [53].

Another advantage is the good permeability with dual porosity, namely micropores (primary porosity) and macropores (secondary fracture porosity) providing convenience for exploration and CBM production activities [53].

A number of state-of-the-art CBM reservoir simulation and exploitation tools have been developed by the University of New South Wales and CSIRO to simulate conventional CBM production and CBM recovery using multi-component gases. On the ground, Australia is working to improve CBM recovery by injecting nitrogen and/or carbon dioxide to increase CBM extraction [53].

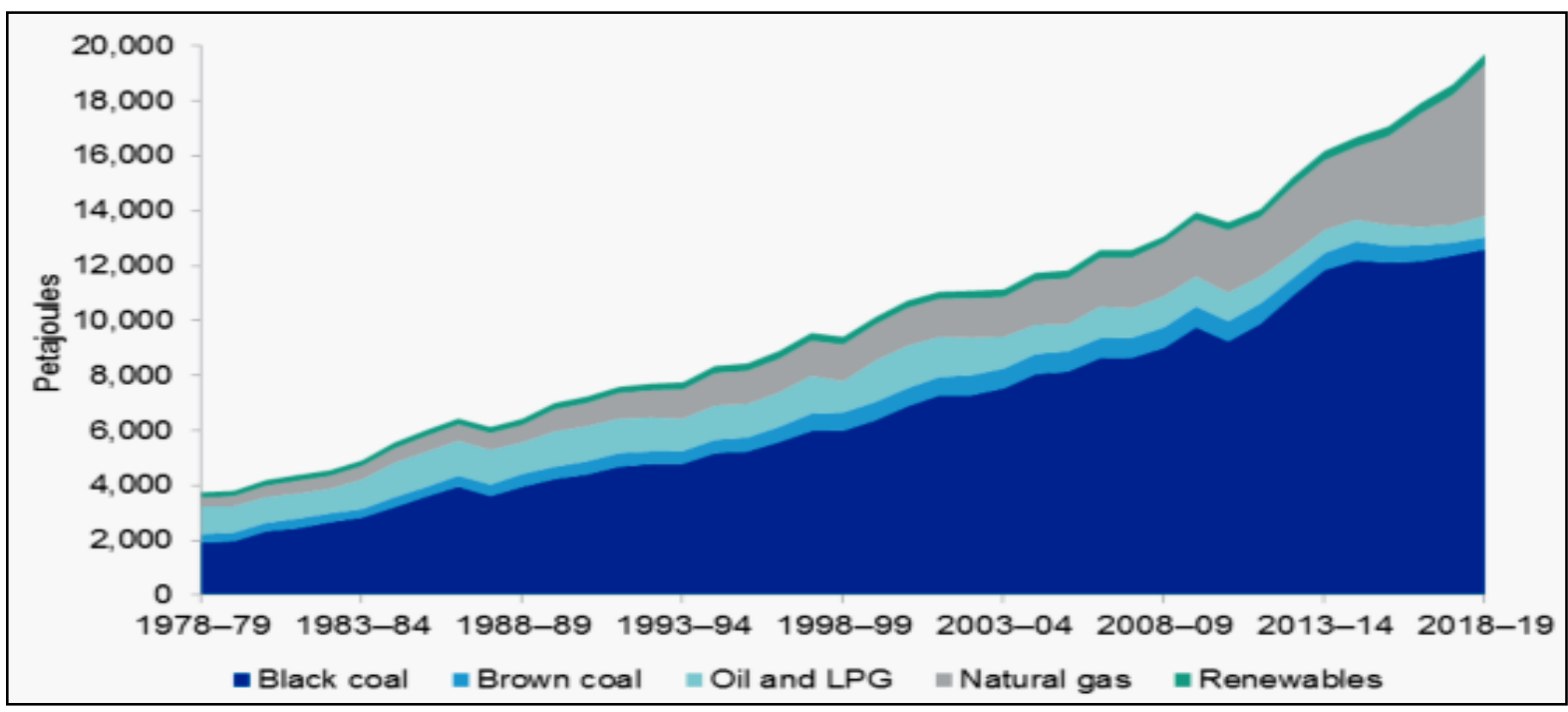

Figure 28: Energy Production in Australia [53] 


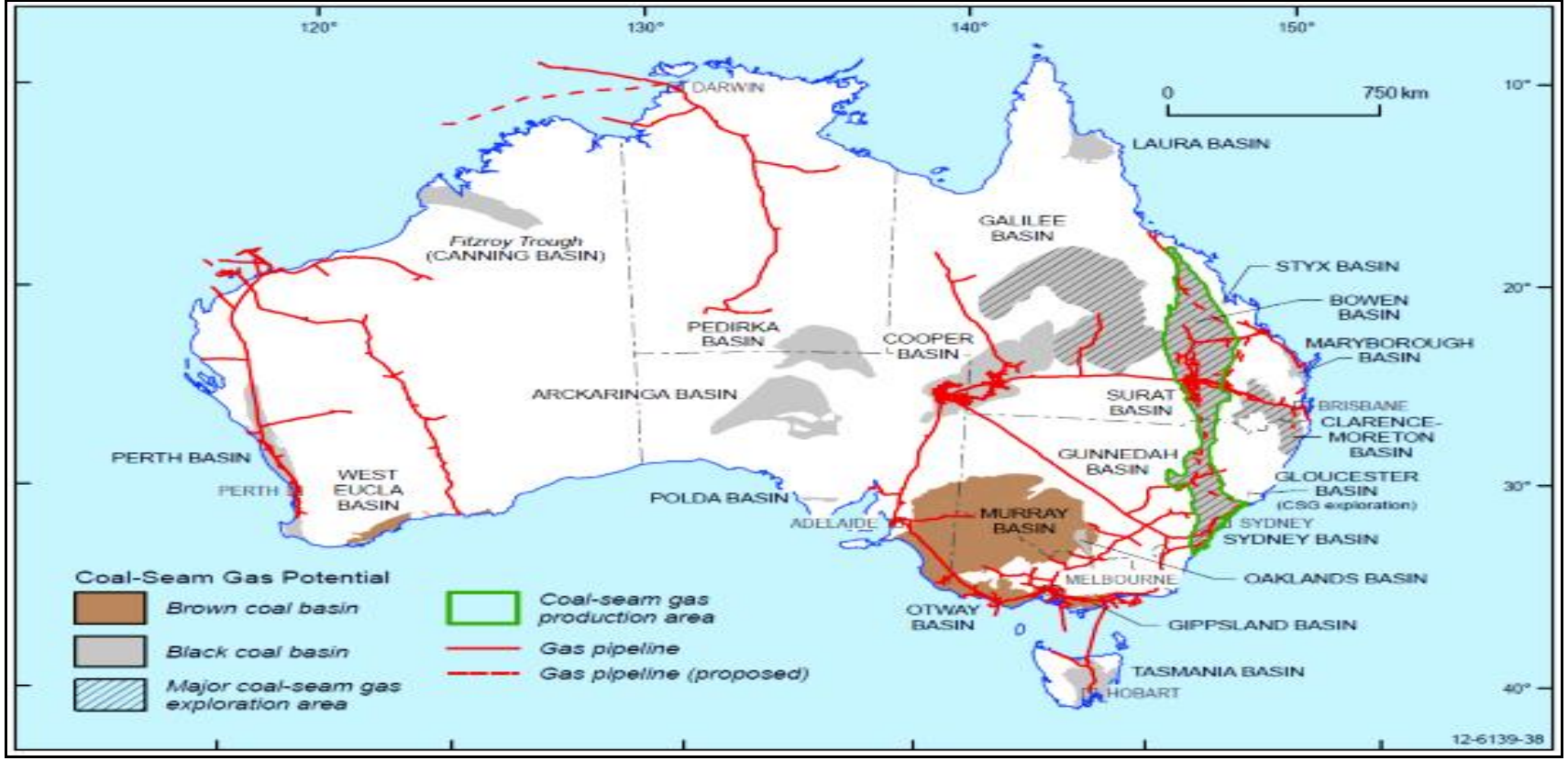

Figure 29: Map of coal basins containing CBM in Australia [53]

\subsection{Develoment of Coalbed Methane in China}

Coal supplied the majority (nearly 66\%) of China's total energy consumption in 2012. Arround $20 \%$ of country's total energy cunsumption was petroleum and other natural liquids. Despite China's efforts to diversify its energy supply, hydroelectric sources $(8 \%)$, natural gas $(5 \%)$, nuclear power (nearly 1\%), and other renewable energies (more than 1\%) account for a relatively small share of China. The Chinese government plans to limit the use of coal to $62 \%$ of total primary energy consumption by 2024 in a bid to reduce the heavy air pollution that has plagued certain areas of the country in recent years. China's National Energy Agency claims that coal use fell to $64.2 \%$ of energy consumption in
2014 [54].

The Chinese government has set a target to increase fossil fuel energy consumption to $15 \%$ of the energy mix by 2020 and to $20 \%$ by 2030 in an effort to reduce the country's dependence on coal. In addition, China is currently increasing its use of natural gas to replace some coal and oil as cleaner fossil fuels and plans to use natural gas for $10 \%$ of its energy consumption by 2020 .

Although absolute coal consumption is expected to increase in the long-term period. As total energy consumption increases, higher energy efficiency and China aims to improve environmental sustainability may lead to a decline in coal share [55].

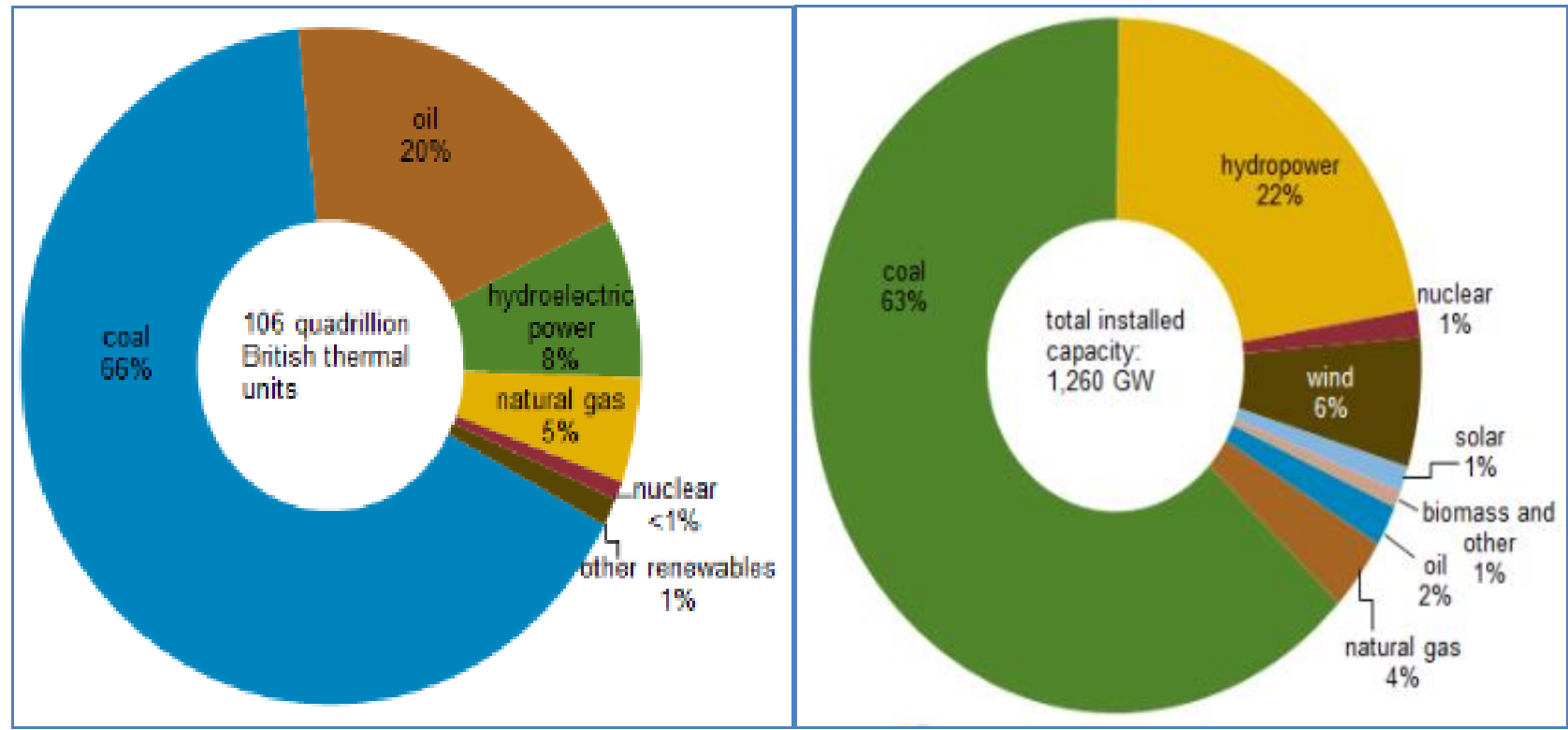

Figure 30: (a) China's energy consumption by fuel types, (b) Installed power plants by fuels [31]. 


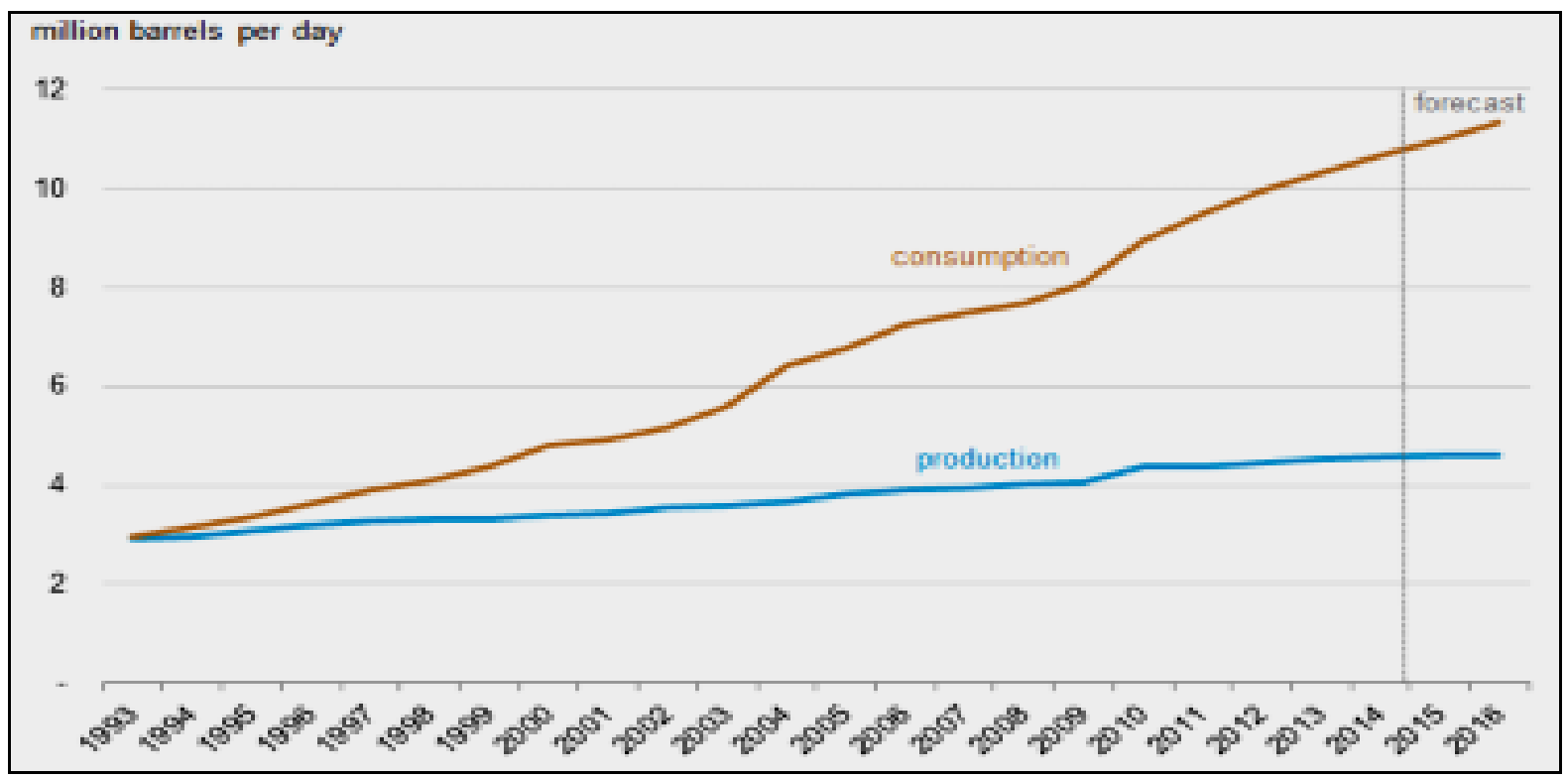

Figure 31: China's Petroleum Production and Consumption [56]

As a result of its high coal consumption, China is also the world's largest emitter of energy-related $\mathrm{CO} 2$, releasing 8,106 million metric tons of $\mathrm{CO} 2$ in 2012. Greenhouse Gas (GHG) emissions from escaping methane and other air pollutants cause environmental problems in the world. China so that the Chinese government is committed to the development and utilization of CBM and is a priority for China's 11th FiveYear Energy Development Plan [31].

In general, the use of CBM in China is caused by plans to reduce energy emissions from coal fuel, methane gas released into the air due to coal mining activities and create clean energy to improve air quality and climate change perspective [56].

The Chinese government's energy policy is dominated by the country's growing demand for oil and its dependence on oil imports. The National Development and Reform Commission (NDRC), a department in China's State Council, is the main policy-making, planning, and regulatory authority of the energy sector, while other ministries such as the Ministry of Commerce, Ministry of Land and Resources, Ministry of Environmental Protection, and State Marine Administration oversees various components of the country's oil policy [56].

The government launched the National Energy Administration (NEA) in 2008 to act as the primary energy regulator. The NEA, linked to the NDRC, is tasked with approving new energy projects in China, setting domestic wholesale energy prices, and implementing the central government's energy policy, among other tasks [56].

In January 2010, the government established a National Energy Commission with the aim of consolidating energy policy among the various agencies under the State Council and assessing key energy issues. Reforms under the leadership of the new government include consolidating and streamlining ministries and expanding the scope of the NEA [56]. In 2004, coal production in China produced about 18 billion cubic meters $(\mathrm{bcm})$ and methane $(\mathrm{CH} 4)$ which was released into the air equivalent to $271 \mathrm{tcm}$ and $106 \mathrm{tcm}$ of Carbon Dioxide (CO2). With an aggressive fuel diversification policy, energy efficiency efforts and reducing the greenhouse effect caused by methane released into the air, the amount of CBM produced in coal mines will increase by about $2 / 3$ by 2021 [57].

Coal mining activities as the main energy source in China cause methane gas to be released into the environment so that gas is installed in most coal mines with large levels of methane gas and built more than $60 \mathrm{CBM}$ utilization projects in the last decade, but only about 10 percent of the total methane gas $(\mathrm{CH} 4)$ from new coal mines that can be captured in 2004 and of the total CBM, only 4.3 percent is utilized. Coal mining activities drain the volume of CBM from underground, but the utilization of this CBM gas has not increased at the same time [58, 59]. China's coal methane $(\mathrm{CBM})$, coaltogas (CTG) or synthetic natural gas (SNG) and shale gas industries are in the early stages of development due to technical challenges and water resources, regulatory barriers, transportation constraints, and competition with fuels and other conventional natural gas. However, China's potential resource wealth has prompted the government to seek foreign investors with the technical expertise to capitalize on it [60].

China's first commercial CBM pipeline entered service in late 2009, connecting the Qinshui Basin with the WesttoEast pipeline. Several other pipelines, mostly in Shanxi Province in north central China, are already operational, and several are under construction.

Table 8: Energy consumption in China [31]

\begin{tabular}{cccccc}
\hline Year & $\begin{array}{c}\text { Energy } \\
\text { Consumption } \\
(\text { Mtce })\end{array}$ & $\begin{array}{c}\text { Coal } \\
(\%)\end{array}$ & $\begin{array}{c}\text { Oil } \\
(\%)\end{array}$ & $\begin{array}{c}\text { LNG } \\
(\%)\end{array}$ & $\begin{array}{c}\text { Hydro } \\
\text { power } \\
(\%)\end{array}$ \\
\hline 1980 & 602.75 & 70.2 & 21.1 & 3.1 & 4 \\
1990 & 987.03 & 76.2 & 16.6 & 2.1 & 5.1 \\
2000 & 1302.97 & 66.1 & 24.6 & 2.5 & 6.8 \\
2003 & 1678.00 & 67.1 & 22.7 & 2.8 & 7.4 \\
2005 & 2220.00 & 68.1 & 21.2 & 2.8 & 7.3 \\
\hline
\end{tabular}




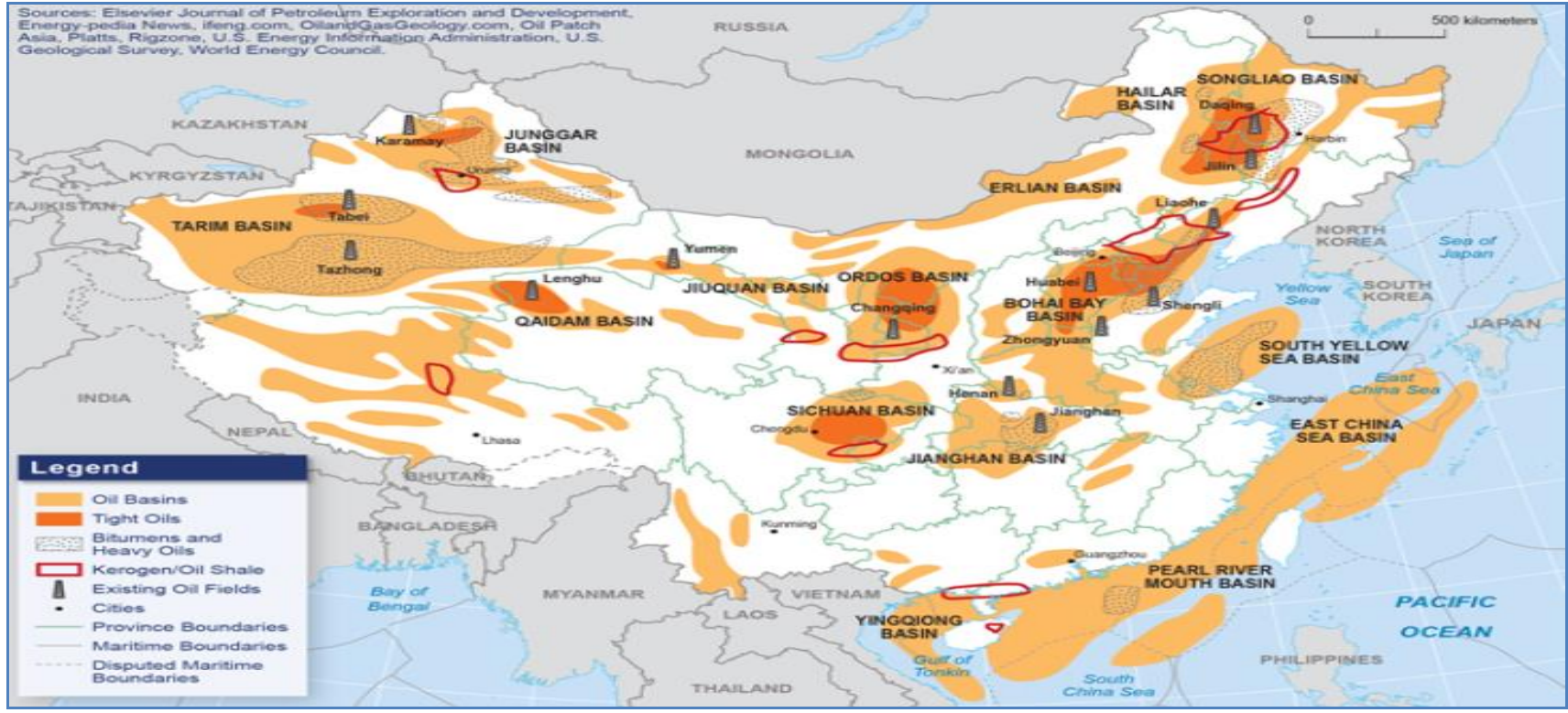

Figure 32: China Energy Field [58]

China operates many small liquefaction plants and transport tanks transporting CBM to demand centers [60]. China lacks clean energy, especially conventional natural gas and the majority of its energy consumption comes from coal (table 6) Proven natural gas reserves per capita are only 1/12 of the world average. However, China has large CBM resources with development potential that can be developed from the mouth of a coal mine [31].

The estimated CBM resource in China is $1012 \mathrm{Tcm}$ at 300 Meters (m) $-2,000 \mathrm{~m}$ below the surface $31.5\left(\mathrm{Tm}^{3}\right)$ comparable to a total estimated resource of $38 \mathrm{Tm}^{3}$ for conventional natural gas, but economically recoverable CBM reserves are much lower due to geological, technological, market, regulatory and institutional constraints. However, to meet its targets, the government must improve the administrative framework for the management of CBM resources, introduce more effective incentives for $\mathrm{CBM}$ development, increase the technical capacity of the mining sector, expand gas pipeline infrastructure, and promote the gas market in coal mining [57]. After 2012, China approved the CBM project so that it could reduce its large coal resources to meet the growing demand for natural gas. The government loosened energy regulations for CBM and provided more economical prices to accelerate the utilization of CBM but the CBM industry is progressing very slowly.

China only produced $75 \mathrm{Bcf}$ in 2014 from two CBM factories operating to run power plants with an installed capacity consumption of $100 \mathrm{Bcf} / \mathrm{year}$ [61]. This is also due to slow technological progress resulting in design and technical errors in this CBM fuel power plant. The Chinese government has approved 15 large-scale CBM projects with a total capacity of more than 2,800 Bcf/year for the other three power plants.

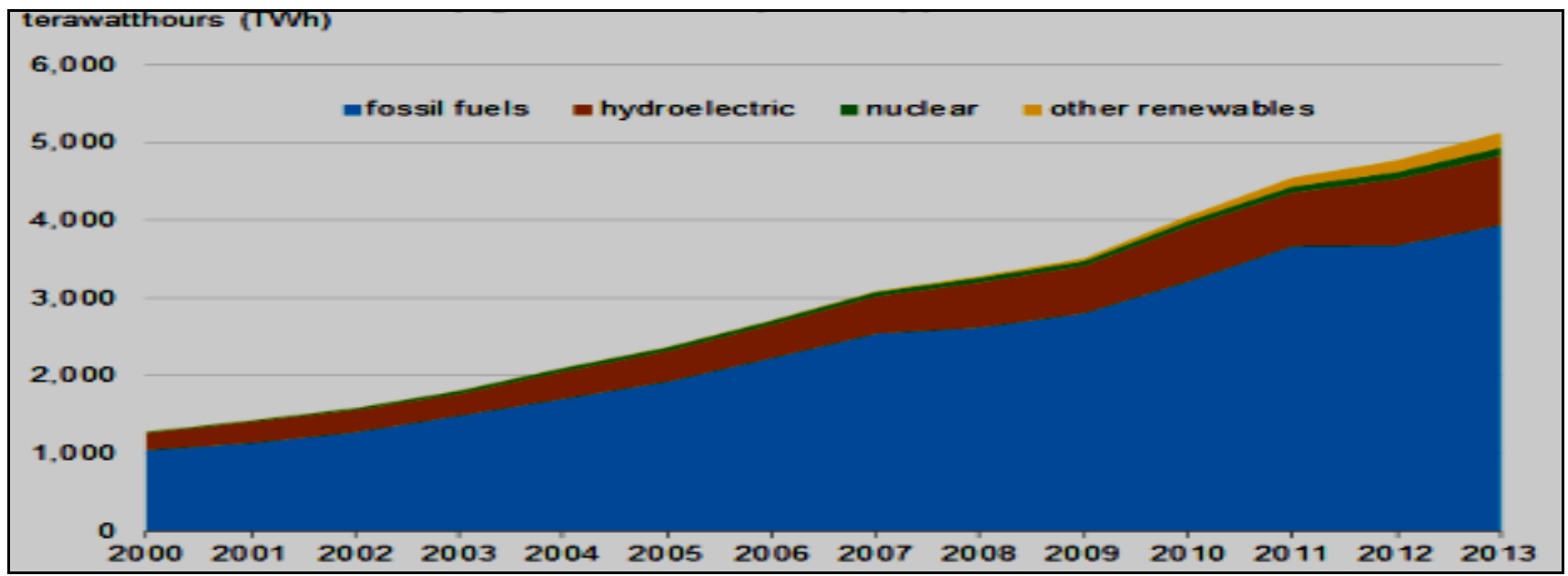

Figure 33: China's Power Generation by Fuels [3] 
Several more facilities are in the planning stages, but CBM projects face high capital costs associated with technology and infrastructure development, scarce water resources, and management of methane released into the [62]. Learning from previous experiences in power plants, China enforces regulations for $\mathrm{CBM}$ plants to be built according to their capacity or at least $70 \mathrm{bcf} / \mathrm{year}$ [57].

Draining CBM wells is time consuming, increasing their overall development costs which is a major challenge for this market. The Chinese market has not yet reached its full potential due to issues ranging from geological conditions, conflicting mining rights, to insufficient subsidies and difficulties in attracting private capital. In addition, there are still doubts on the quality, quantity and distribution of water from the coal seam [62].

Currently, China is learning from technology and government regulations that have been developed previously in the United States and Australia, especially on the overlapping regulations and more competitive market pricing [63].

To overcome the constraints of exploration, production and utilization of CBM, the Chinese government does the following:

1. Strengthen CBM policies, legal and regulatory frameworks to improve resource management;

2. Increase the availability and quality of CBM so that more can be utilized;

3. Increase incentives to encourage expansion of CBM exploitation.

4. Learn about technology and regulatory regulations in countries that have developed CBM production, such as the United States and Australia.

5. Promote the development of regional development strategies to take advantage of certain local advantages.

6. Limitation of CBM fuel power plants to a minimum of 70 Bcf/year.

\subsection{CONCLUSIONS AND SUGGESTIONS}

\subsection{Conclusions}

1. The search and use of new energy in the world is caused by the reduction of conventional fossil energy reserves.

2. Environmental problems and the greenhouse effect due to $\mathrm{CH} 4$ and $\mathrm{CO} 2$ emissions result in the urgent need to use more environmentally friendly energy with the smallest possible greenhouse production.

3. The world's huge reserves of new CBM energy that have not been exploited because it used to be considered a major problem in coal mines that caused mining accidents and eventually methane gas was released and caused the greenhouse effect.

4. The low energy mix in some countries causes energy crisis if there are conditions of reduced supply or technical problems and power plant infrastructure.

5. There are many problems in accelerating the utilization of CBM in developing countries, namely the constraints of developing exploration, production and utilization of CBM, geological and coal permeability problems, lack of infrastructure, large initial capital and POD costs during the dewatering process, CBM prices are still influenced by oil prices. and coal, regulations in many countries regarding $\mathrm{CBM}$ are not appropriate because they refer to oil, gas and coal regulations.

\subsection{Suggestions}

1. To accelerate the development of exploration, production and utilization of CBM, it is necessary to conduct comparative studies and case studies from several countries with large CBM reserves or from countries that have developed CBM utilization.

2. Temporary oil and gas and coal regulations are not suitable to be applied to the CBM industry because the government still needs to provide tax breaks, application of subsidies/incentives, more flexible POD regulations because it requires large costs for dewatering for 7 years.

3. The study of CBM-fueled power plants must be $10 \%$ below CBM production so that there is no overbuilt like what happened in China.

\section{REFERENCE}

[1] Nasruddin, Martin, A., Alhamid, M.I. and Tampubolon, D. (2017). Adsorption Isotherms of Hydrogen on Granular Activated Carbon Derived From Coal and Derived From Coconut Shell, Heat Transfer Engineering, 38(4), 403-408.

[2] Wyman, O. (2019). World Energy Trilemma Index. Wol, VAT Reg. No. GB 1233802 48, 13-14.

[3] Looney, B. (2020). BP Statistical Review of World Energy, 69th edition.

[4] World Energy Outlook. (2019). INTERNATIONAL ENERGY AGENCY, https://www.iea.org/topics/worldenergy-outlook. Accessed 20 Juni 2021.

[5] Carbon Dioxide Information Analysis Center. (2020). https://cdiac.ess-dive.lbl.gov/. Accessed 21 Juni 2021.

[6] Energy Content of some Combustibles (in MJ $/ \mathrm{kg}$ ) Archived January 9 (2014), at the Wayback Machine. People.hofstra.edu. Retrieved on March 30, 2014.

[7] Mitchell, Logan, et al, (2013). Constraints on the late holocene anthopogenic constributio to the atmospheric methane, Science 342 (6161):964-966. Doi : 10.1126/science. 1238920 .

[8] Bubier, Jill L, Moore, Tim R. (1994). An ecological perspective on methane emissions form northern wetlands, 9(12), 460-464. Doi: 10.1016/01695347(94)90309.

[9] Technical summary, Climate change (2001), United Nations Environment Programmee.

[10] Shindell, D.T. et al, (2009). Improved attribtion of climate forcing to emission, Science, 326 (5953): 716-8. Doi : 10.1126/science.11.74760.

[11] Methane Emissions? Don't Blame Plants, ScienceNOW, 14 January 2009. Accessed 20 Juni 2021.

[12] Matheson Tri. (2009). Safety Data Sheet: Methane. Matheson Tri-Gas. Archived from the original (PDF) on 2018-12-26

[13] Clayton, B. and Cornell (2008), Natural gas cars : CNG fuel almos free in some parts of the country.

[14] Energy content of some fuels (in MJ/kg), (2014), Wayback Engine.

[15] Haldar, S.K. (2018). Elements of Mining. Mineral 
Exploration, 229-258. doi:10.1016/b978-0-12-8140222.00012-5.

[16] Iwan Sukma Gumilar (2020). Migas Non Konvensional : Jenis dan Potensi di Indonesia, Webinar, http://bit.ly/Geoseminar27Okt2020. Accessed 20 Juni 2021.

[17] Coalbed methane: clean energy for the world (2020). United States Geological Survey USGS. (2020). https://pubs.er.usgs.gov/publication/70034970, accessed 21 April 2021.

[18] Demirbas, A. (2010). Methane gas hydrate. Spriger. ISBN 1-84882-871-3, 6-7

[19] Sun, Z., Li, X, et al. (2018). A semi-analytical model for the relationship between pressure and saturation in the CBM reservoirs, Journal of Natural Gas Science and Engineering, 49,365 -

375. Doi:10.1016/j.jngse.2017.11.022.

[20] Fadhilah, A. (2017). Mengenal 3 Potensi Energi Baru dan Penerapannya di Indonesia. https://medium.com/@alfinfadhilah/mengenal-3potensi-energi-baru-dan-penerapannya-di-indonesia91b5b98ab89b. Accessed 21 Juni 2021.

[21] Rosyadi, H. (2015). Potensi Coalbed Methane untuk Mensukseskan Program Diversifikasi Energi Nasional, https://www.researchgate.net/publication/282183107.

[22] Sumiarso, L. (2007), https://www.esdm.go.id/id/media-center/arsipberita/potensi-cbm-indonesia-sekitar-450-tcf. Accessed 18 April 2021.

[23] Widodo, Aruman (2006). Peluang CBM sebagai Energi Alternatif di Masa Depan. Ikatan Sarjana Ekonomi Indonesia.

[24] Lennon, L. (2021), Coalbed methane: economic boon or environmental boondoggle, Montana State University. https://serc.carl.

[25] Pashin, J.C. et al, (1990). Geologic evaluation of critical production parameters for Coalbed methane resources, Annual report, part II, black warrior basin, gas research Inst., Chicago, Illinois, 130.

[26] Rogers, R.E. (1994). Coalbed Methane: Principles and Practice, 345. Englewood Cliffs, New Jersey: Prentice Hall.

[27] Warr, S. and Harman, J. (2000). Prospects for Cogeneration in Australia, Australian Cogeneration Association Submission to NECA. https://search.informit.org/doi/epdf/10.3316/ielapa.2525 07747514157. Accessed 20 Juni 2021.

[28] Sarhosis, V., Jaya, A.A. and Thomas, H.R. (2016) Economic modelling for coal bed methane production and electricity generation from deep virgin coal seams, 7-9. Doi: 10.1016/j.energy.2016.04.056 .

[29] Sarhosis V, Jaya, A.A., Hosking L.J., Koj, A., Thomas H.R. (2015). Techno-economics for coal bed methane production in the South Wales Coalfield. In: Clean Coal Technology Conference (CCT2015), Kraków, Poland: IEA Clean Coal Center.

[30] Coal Bed Methane Market Size, Share \& Trends Analysis Report by Application (Industrial, Residential, Commercial, Power Generation, Transportation), by Region, and Segment Forecasts 2020 - 2027. (2020). ID:978-1-68038-028-6.

https://www.grandviewresearch.com/industry- analysis/coal-bed-methane-industry. Accessed 20 Juni 2021.

[31] Global Energy Statictical Yearbook. (2020). https://yearbook.enerdata.net/. Accessed 21 Juni 2021.

[32] World Energy Transition Outlook $1.5^{\circ} \mathrm{C}$ Pathway. (2021). International Renewable Energy Agency, Abu Dhabi. ISBN : 978-92-920-334-2.

[33] ECBM Sequestration Knowledge Base Progress Reports. (2003). Advanced Resources International, Inch. https://adv-res.com/Coal-Seq_Consortium/coalseq-technical-reports-phase-II -III.php. Accessed 20 Juni 2021.

[34] Carbon credit, Collins English Dictionary (2012), Complete \& Unabridged 11th Edition.

[35] Susilawati, R. (2020). Mengenal GMB dan potensinya di Indonesia. Geological Agency of Indonesia. Wink2proud@gmail.com

[36] Indonesia Energy Outlook. (2019). Secretariat General National Energy Council. ISSN 2527-3000.

[37] Buku Peta Jalan Kebijakan Gas Bumi Nasional 2014 2030 (2015). Ministry of Energy And Mineral Resources. Republic of Indonesia.

[38] Ministry of Energy And Mineral Resources (2014). Republic of Indonesia. https://www.esdm.go.id/en/media-center/newsarchives/wamen-esdm-buka-indocbm-2014.

[39] Pertamina Energy Institute (2019), Pengembangan Potensi Sumber Daya Domestik, Buletin Pertamina 01, ISSN. 3621-5012.

[40] Director of Primary Energy PLN (2010). Ministry of Energy And Mineral Resources. https://www.esdm.go.id/id/media-center/arsip-berita/plnsiap-beli-cbm. Accessed 21 Juni 2021.

[41] Makarov, A.A. (2020). Global and Russian Energy Outlook up To 2040. The Energy Research Institute of The Russian Academy of Sciences, Analytical Center For the Government of The Russian Federation

[42] Kuznetsova, A. (2020). Energy consumption structure and economic growth in the Russian Federation. IOP Publishing Ltd, 10-16 doi:10.1088/1757899X/734/1/012206.

[43] GAZPROM (2019). Development of coalbed methane in Russia: First result and prospects, CBM Project implementation.

[44] Alexander Karasevich, Promgaz (2005), Current state and prospects of Coalbed Methane (CBM) production in Russia.

[45] U.S. EPA. Report. (2015). U.S. Environmental Protection Agency (EPA). National Homeland Security Reseearch Center. 600/R-15/283. https://cfpub.epa.gov/si/si_public_record_report.cfm. Accessed 21 Juni 2021.

[46] M2M-Workshop. (2005). Coal Mine and Coalbed Methane. https://www.globalmethane.org/. Accessed 21 Juni 2021.

[47] Tailakov, V., Utkaev, E.A and Kormin, A.N. (2019). Intensification of gas recovery from coal seams applying the method of hydrodynamic impact in horizontal boreholes, Earth and Environmental Science, 377, 20-40. doi:10.1088/1755-1315/377/1/012047.

[48] Peter D. Saundry (2019). Review of the United States energy system in transition. Energy sustainability and society, 3-10. Doi : 10.1186/s13705-018-0178-8. 
[49] Publications of the US Geological Survey (1997). U.S. Geological Survey. https://pubs.usgs.gov/unnumbered/70043744/report.pdf] . Accessed 21 Juni 2021.

[50] Zou, C. (2017). CBM. Unconventional Petroleum Geology, 323-344. Doi:10.1016/b978-0-12-8122341.00011-x.

[51] Department of Industry, Science, Energy and Resources (2020. Australian Energy Update 2020, Australian Energy Statistics, September, Canberra.

[52] Australian Energy Update (2020). Australian Energy Statistic.

https://www.energy.gov.au/sites/default/files/Australian $\% 20$ Energy\%20Statistics\%202020\%20Energy\%20Upd ate\%20Report_0.pdf. Accessed 21 Juni 20211.

[53] Australia's national science agency and innovation catalyst. (2019). https://ecos.csiro.au/tag/coal-seam-gas/. Accessed 21 Juni 2021.

[54] Protocol on Energy Efficiency and Environmental Aspects (2015). China energy efficiency report. China National Energy Administrations. ISBN: 978-905948203-6.

[55] IHS Energy, Coal Rush: The Future of China's Coal Ma rket (2013). Chapter 2, page II6; and National Bureau of Statistics, China Statistical Yearbook 2014.

[56] International energy outlook. (2016). U.S. Energy. Information administration.
HTTPS://WWW.EIA.GOV/OUTLOOKS/IEO/PDF/048 4(2016).PDF. ACCESSED 20 JUNI 2021.

[57] China renewable energy outlook. (2016). Https://www.ea-energianalyse.dk/en/publications/chinarenewable-energy-outlook-2016-chinese-version/. Accessed 21 Juni 2021.

[58] National Development and Reform Commission, China's Policies and Actions on Climate Change (2014) , November2014; Vinson \& Elkins, Climate Change Blo g, China's National Plan for Climate Change (20142020).

[59] Reuters (2014) China CO2 emissions to rise by one third before $2030 \mathrm{p}$ eak study.

[60] IEA

Update on Overseas Investments by China's National Oi 1 Companies.

[61] European Dialogue (2014). CPC, KazakhstanChina Pipeline to Expand, KazMunayGas.

[62] Energy Sector Management Assistance Program. (2007). Strategy for Coal Bed Methane (CBM) and Coal Mine Methane (CMM) Development and Utilization in China.

[63] Zou, C. (2017). In Unconventional Petroleum Geology (Second Edition). 